NBER WORKING PAPER SERIES

\title{
GLOBAL MACRO RISKS IN CURRENCY EXCESS RETURNS
}

\author{
Kimberly A. Berg \\ Nelson Mark \\ Working Paper 23764 \\ http://www.nber.org/papers/w23764
NATIONAL BUREAU OF ECONOMIC RESEARCH
1050 Massachusetts Avenue
Cambridge, MA 02138
September 2017

This paper has benefited from presentations at American University, Bank of Canada, the 2015 Canadian Economic Association Meetings, Colby College, Federal Reserve Bank of Chicago, Miami University, Notre Dame Seminars, Sam Houston State University, University of Colorado, University of New Hampshire, University of Mississippi, University of North Carolina, 2015 WAMS Sydney, and 2016 Workshop on Macroeconomic Uncertainty at University College London, and 6th Workshop on Financial Determinants of Foreign Exchange Rates, Bank of England. We thank Tom Cosimano, Alex Maynard, and especially, an anonymous Associate Editor for comments that helped improve the paper. All errors are our own. The views expressed herein are those of the authors and do not necessarily reflect the views of the National Bureau of Economic Research.

NBER working papers are circulated for discussion and comment purposes. They have not been peer-reviewed or been subject to the review by the NBER Board of Directors that accompanies official NBER publications.

(C) 2017 by Kimberly A. Berg and Nelson Mark. All rights reserved. Short sections of text, not to exceed two paragraphs, may be quoted without explicit permission provided that full credit, including (C) notice, is given to the source. 
Global Macro Risks in Currency Excess Returns

Kimberly A. Berg and Nelson Mark

NBER Working Paper No. 23764

September 2017

JEL No. F3,F4,G1

\title{
ABSTRACT
}

We study the cross-sectional variation of carry-trade-generated currency excess returns in terms of their exposure to global macroeconomic fundamental risk. The risk factor is the cross-country high-minus-low conditional skewness of the unemployment rate gap. It gives a measure of global macroeconomic uncertainty and is robustly priced in currency excess returns. A widening of the high-minus-low skewness of the unemployment rate gap signifies increasing divergence, disparity, and inequality of economic performance across countries.

\author{
Kimberly A. Berg \\ Department of Economics \\ Miami University \\ Oxford $\mathrm{OH}$ \\ bergka@miamioh.edu \\ Nelson Mark \\ Department of Economics \\ University of Notre Dame \\ 434 Flanner \\ Notre Dame, IN 46556 \\ and NBER \\ nmark@nd.edu
}




\section{Introduction}

In this paper, we study the cross-sectional variation of carry-trade-generated portfolios of currency excess returns as a function of their exposure to systematic global macroeconomic risk. The proposed risk factors are high-minus-low differences between the top and bottom quartiles of conditional moments of country-level macroeconomic performance indicators. Movements in these easily computable risk factors are interpreted to reflect variations in global economic uncertainty. The high-minus-low concept is used extensively in finance. By sorting into quartiles, our high-minus-low variable is similar to the interquartile range, which is a robust measure of distributional dispersion and thus captures an important aspect of global uncertainty. Our analysis includes conditional first, second, and third moments of country-level macroeconomic data. Conceptually, conditional second and third moments measure some aspect of country-specific macroeconomic risk and uncertainty, while the high-minus-low differences capture aspects of global risk and uncertainty.

Our main result is that the high-minus-low conditional skewness $\left(\mathrm{HML}_{\text {skew }}\right)$ of the unemployment rate gap is a global macroeconomic fundamental risk factor, robustly priced into the carry-trade-generated currency excess returns. ${ }^{1}$ The connection of the unemployment gap to currency returns, is that it is a variable of interest to central banks in conducting monetary policy and setting the policy rate (Orphanides and Williams (2005, 2006, and 2007)). At the country level, negative conditional skewness of the unemployment gap represents a high probability of lower than normal unemployment, while positive values represent a high probability of higher than normal unemployment. Whether a country's conditional skewness is negative or positive, an increase in the measure is generally not good. The global factor is the high-minus-low across country-level unemployment gap skewness. An increase in the factor is an increase in global uncertainty-a widening and

\footnotetext{
${ }^{1}$ We use the terms unemployment rate gap and unemployment gap interchangeably.
} 
increased dispersion of the economic state across countries. In a globally integrated financial market, investors pay attention to the state of the global economy as summarized by global risk factors.

A legacy literature sought to understand currency excess returns by trying to resolve the forward premium anomaly-recognized as an empirical regularity since Hansen and Hodrick (1980), Bilson (1981), and Fama (1984). ${ }^{2}$ Although the forward premium anomaly implies non-zero currency excess returns, they are two different and distinct phenomena (Hassan and Mano (2014)). Recent research in international finance has de-emphasized the forward premium anomaly, focused directly on currency excess returns, and has produced new insights. A methodological innovation introduced by Lustig and Verdelhan (2007), was to change the observational unit from individual returns to portfolios of returns. Identification of systematic risk in currency excess returns has long posed a challenge to this research, and the use of portfolios aids in this identification by averaging out idiosyncratic return fluctuations. Since the returns are available to global investors, and portfolio formation allows diversification of country-specific risk, presumably only global risk factors remain to drive portfolio returns. Following the recent literature, our test assets are interest-rate ranked portfolios of currency excess returns.

The factor is constructed by computing the conditional skewness of each country's unemployment gap and subtracting the average of the bottom quartile of countries from the average of the top quartile. The factor is robust to alternative conditional moments (mean and volatility), alternative macro fundamentals (change in unemployment rate, output

\footnotetext{
${ }^{2}$ Regressions of the future currency depreciation on the interest differential typically give a negative slope coefficient in violation of the zero-profit uncovered interest rate parity (UIP) condition. Hodrick (1987), Engel (1996), and Lewis (1995) survey earlier work on the topic, which viewed excess returns as risk premia and emphasized the time-series properties of individual currency excess returns. Whether through estimation or quantitative evaluation of asset pricing models, explanatory power was low and this body of work was unable to produce or identify mechanisms for risk premia that were sufficiently large or acceptably correlated with the excess returns. This is not to say interest in the topic has waned. See, for example, Alvarez et al. (2009), Bansal and Shaliastovich (2012), Chinn and Zhang (2015), Engel (2016), and Verdelhan (2010).
} 
gap, output growth, real exchange rate gap, real exchange rate depreciation, consumption growth, and inflation rate), and the two risk factors (dollar risk factor and carry trade risk factor) for currency excess returns considered by Lustig et al. (2011). The significance of the conditional skewness measure underscores the importance of asymmetries in the state of nature-asymmetries which are obscured by volatility measures of uncertainty.

While the $\mathrm{HML}_{\text {skew }}$ of the unemployment gap factor looks like a risk factor to the portfolio returns, the mechanism differs across portfolios. The betas for low interest (and hence low currency excess return) portfolios are negative. This is due primarily to the exchange rate component. Currencies in these portfolios lose value when there is an increase in global uncertainty, as measured by the factor. In contrast, beta on the high interest portfolio is positive, primarily on account of the interest rate component of returns. When the factor spikes up, the yields in this portfolio increase as global investors flee the debt of these countries. The currencies of the high interest portfolio countries also fall in the bad state but not enough to offset the increase in the interest rate differential.

In a complete-markets setting, the carry-trade-generated excess returns are priced by our $\mathrm{HML}_{\text {skew }}$ of the unemployment gap if country-level stochastic discount factors (SDF) load heterogeneously on the global factor. How much heterogeneity is there in SDF global factor loadings? We explore this issue with two illustrative examples. In the first instance, we report on heterogeneity in individual consumption growth exposure to the factor. In a world of constant relative-risk aversion utility, consumption growth is proportional to the $\log$ SDF. Our second illustration examines the heterogeneity in SDF loadings on the global factor from simulated method of moments estimation of an affine yield model (adapted from Lustig et al. (2011) and Backus et al. (2001)) of the term structure of interest rates, applied to pricing currency excess returns. Simulations of this reduced form model show that estimated heterogeneity in the loadings on $\mathrm{HML}_{\text {skew }}$ of the unemployment gap qualitatively replicates key features of the data. 
Our paper is part of a literature that studies portfolios of currency excess returns in the context of asset pricing models and is closest to the absolute asset pricing strand of the literature, which examines currency returns in terms of their exposure to macroeconomic fundamental risk (Lustig and Verdelhan (2007), Burnside et al. (2011), Jorda and Taylor (2012), Hassan (2013), Menkhoff et al. (2013), and Della Corte et al. (2013), Ready et al. (2015), and Colacito et al. (2015)). The relative asset pricing strand (Lustig et al. (2011), Daniel at al. (2014), and Ang and Chen (2010)) studies risk factors built from other asset returns. Clarida et al. (2009) and Christiansen et al. (2011) focus on regime switches. Our paper is also aligned with a strand of the literature that connects notions of uncertainty to currency excess returns. Menkhoff et al. (2012) price returns to global foreign exchange volatility, Della Corte et al. (2015) price currency returns to sovereign risk, Brunnermeier et al. (2008), Jurek (2014), and Lettau et al. (2014) study the relation of returns to crash risk.

Although our paper is mainly empirical, from a macroeconomic modeling perspective, an improved understanding of currency excess returns can help inform future developments in modeling uncovered interest rate parity shocks. Frequently, macro models impose exogenous dynamics into deviations from uncovered interest rate parity (UIP) for the models to generate realistic exchange rate dynamics (Kollmann (2002), Devereux and Engel (2003), Engel (2015), and Itskhoki and Mukhin (2016)). An empirical analysis, such as ours, may aid in developing general equilibrium models with endogenous deviations from UIP.

The remainder of the paper is organized as follows. The next section discusses the construction of portfolios of currency excess returns. Section 2 describes the data, Section 3 describes the construction of the macroeconomic risk factors, Section 4 implements the main empirical work, Section 5 presents the affine asset pricing model, and Section 6 concludes. 


\section{Portfolios of Currency Excess Returns}

Identification of systematic risk in currency returns has long posed a challenge in international finance. In early research on single-factor models (e.g., Frankel and Engel (1984), Cumby (1988), and Mark (1988)), the observational unit was the excess U.S. dollar return against a single currency. Lustig and Verdelhan (2007) innovated on the methodology by working with portfolios of currency excess returns instead of returns for individual currencies. This is a useful way to organize the data because it averages out noisy idiosyncratic and non-systematic variation and improves the ability to uncover systematic risk. Since global investors have access to these returns, they can form such portfolios and diversify away country-specific risk. In a world of integrated financial markets, only undiversifiable global risk factors should be priced.

Before forming portfolios, we start with the bilateral carry trade. Let there be $n_{t}+1$ currencies available at time $t$. Let the nominal interest rate of country $i$ be $r_{i, t}$ for $i=1, \ldots, n_{t}$, and the U.S. nominal interest rate be $r_{0, t}$. The United States will always be country '0.' In the carry, we short the U.S. dollar (USD) and go long in currency $i$ if $r_{i, t}>r_{0, t}$. The expected bilateral excess return is

$$
E_{t}\left(\left(1+r_{i, t}\right) \frac{S_{i, t+1}}{S_{i, t}}-\left(1+r_{0, t}\right)\right) \simeq E_{t}\left(\Delta \ln \left(S_{i, t+1}\right)\right)+r_{i, t}-r_{0, t}
$$

where $S_{i, t}$ is the USD price of currency $i$ (an increase in $S_{i, t}$ means the USD depreciates relative to currency $i$ ). If $r_{0, t}>r_{i, t}$, we short currency $i$ and go long in the USD. ${ }^{3}$

Next, we extend the carry trade to a multilateral setting. We rank countries by interest rates from low to high in each time period and use this ranking to form portfolios of currency excess returns. As in Lustig et al. (2011), we form six such portfolios, called $P_{1}, \ldots, P_{6}$. The portfolios are rebalanced every period. Portfolios are arranged from low $\left(P_{1}\right)$ to high $\left(P_{6}\right)$,

\footnotetext{
${ }^{3}$ The right hand side of equation (1) is the excess return in log-units.
} 
where $P_{6}$ is the equally weighted average return from those countries in the highest quantile of interest rates and $P_{1}$ is the equally weighted average return from the lowest quantile of interest rates. Excess portfolio returns are stated relative to the U.S.,

$$
\frac{1}{n_{j, t}} \sum_{i \in P_{j}}\left(1+r_{i, t}\right) \frac{S_{i, t+1}}{S_{i, t}}-\left(1+r_{0, t}\right)
$$

for $j=1, \ldots, 6$. In this approach, the exchange rate components of the excess returns are relative to the USD. The USD is the funding currency if the average of $P_{j}$ interest rates are higher than the U.S. rate and vice-versa. An alternative, but equivalent approach would be to short any of the $n_{t}+1$ currencies and to go long in the remaining $n_{t}$ currencies. Excess returns would be constructed by 'differencing' the portfolio return, as in Lustig et al. (2011) and Menkhoff et al. (2013), by subtracting the $P_{1}$ return from $P_{2}$ through $P_{6} \cdot{ }^{4}$ It does not matter, however, whether excess returns are formed by the 'difference' method or by subtracting the U.S. interest rate. As Burnside (2011a) points out, portfolios formed by one method are linear combinations of portfolios formed by the other. The next section describes the data we use to construct the portfolios of currency excess returns.

\section{The Data}

The raw data are quarterly and have a maximal span from 1973Q1 to 2014Q2. When available, observations are end-of-quarter and point-sampled. Cross-country data availability varies by quarter. At the beginning of the sample, observations are available for 11 countries. The sample expands to include additional countries as their data become available,

\footnotetext{
${ }^{4}$ If there are $n_{j, t}$ currencies (excluding the reference currency) in portfolio $P_{j}$, the USD ex post $P_{6}-P_{1}$ excess return is

$$
\frac{1}{n_{6, t}} \sum_{i \in P_{6}}\left(1+r_{i, t}\right) \frac{S_{i, t+1}}{S_{i, t}}-\frac{1}{n_{1, t}} \sum_{k \in P_{1}}\left(1+r_{k, t}\right) \frac{S_{k, t+1}}{S_{k, t}} .
$$


and contracts when data vanish (as when countries join the euro). Our encompassing sample is for 41 countries plus the euro area. The countries are Australia, Austria, Belgium, Brazil, Canada, Chile, Colombia, the Czech Republic, Denmark, Finland, France, Germany, Greece, Hungary, Iceland, India, Indonesia, Ireland, Israel, Italy, Japan, Malaysia, Mexico, the Netherlands, New Zealand, Norway, the Philippines, Poland, Portugal, Romania, Singapore, South Africa, South Korea, Spain, Sweden, Switzerland, Taiwan, Thailand, Turkey, the United Kingdom, and the United States. The data set consists of exchange rates, interest rates, consumption, gross domestic product (GDP), unemployment rates, and the consumer price index (CPI). The macro data are not seasonally adjusted. Census seasonal adjustment procedures impound future information into today's seasonally adjusted observations, which is generally unwelcome. We remove the seasonality ourselves with a moving average of the current and three previous quarters of the variable in question.

Currency returns are formed using interbank interest rates and spot exchange rates. The exchange rate, $S_{j, t}$, is expressed as USD per foreign currency units so that a higher exchange rate represents an appreciation of the foreign currency relative to the USD. The data source from 1996Q1 to 2014Q2 is Datastream for three-month yields and Bloomberg for exchange rates. Before 1996, coverage from both sources was very thin. To extend the sample back to 1973Q1, exchange rates and interest rates for Australia, Belgium, Canada, France, Germany, Italy, Japan, the Netherlands, Switzerland, the United Kingdom, and the United States are from the Harris Bank Weekly Review. These are quotations from the last Friday of the quarter from 1973Q1 to 1995Q4.

One consideration in selecting countries in our sample was based on the availability of rates on interbank or Eurocurrency loans, which are assets for which traders can take short positions. Because the rates for alternative currencies are often quoted by the same bank, Eurocurrency/interbank rates net out cross-country differences in default risk. Imputing interest rates from the foreign exchange forward premium is not a good idea since covered 
interest parity has been reported to fail since the onset of the global financial crisis (Pinnington and Shamloo (2016) and Du et al. (2016)). ${ }^{5}$ Additional details on the interest rate data are provided in Appendix A.

Real consumption and GDP are from Haver Analytics. The unemployment rate and the consumer price index $\left(P_{j, t}\right)$ are from the FRED database at the Federal Reserve Bank of St. Louis. The log real exchange rate between the United States (country ' 0 ') and country $j$ is $q_{j, t} \equiv \ln \left(\left(S_{j, t} P_{j, t}\right) / P_{0, t}\right)$.

In many cases, because of the relatively short time span of the data, the real exchange rate and unemployment rate appear to be non-stationary. To induce stationarity in these variables, we work with their 'gap' versions. The gap variables are cyclical components from a recursively applied Hodrick-Prescott (1997) (HP) filter. The HP filter is applied recursively so as not to introduce future information into current observations. The GDP gap is constructed similarly. The next section discusses the construction of the macroeconomic risk factors using the data described above.

\section{Global Macro Fundamental Risk in Currency Ex- cess Returns}

This section addresses the central issue of the paper. Does the cross-section of carrytrade-generated currency excess returns vary in proportion to their exposure to risk factors based on macro-fundamentals? Burnside et al. (2011) found little evidence that any macrovariables were priced. Lustig and Verdelhan's (2007) analysis of U.S. consumption growth as a risk factor was challenged by Burnside (2011a). Menkhoff et al. (2012) price carrytrade portfolios augmented by portfolios formed by ranking variables used in the monetary

\footnotetext{
${ }^{5}$ We also found imputed interest rates to be excessively volatile and were often negative (in periods before central banks began paying negative interest).
} 
approach to exchange rates.

The macroeconomic performance indicators we consider are,

1. Unemployment rate gap, $U E^{g a p}$

2. Change in unemployment rate, $\Delta U E$

3. GDP growth, $\Delta y$

4. GDP gap, $y^{g a p}$

5. Real exchange rate gap, $q^{g a p}$

6. Real exchange rate depreciation, $\Delta q$

7. Aggregate consumption growth, $\Delta c$

\section{Inflation rate, $\pi$}

The rationale for the unemployment rate, consumption growth, and GDP measures is obvious. Both the gap and rates of change are employed to induce stationarity in the real exchange rate, unemployment rate, and GDP observations. The output gap is a key variable of interest to central banks in the conduct of monetary policy and setting the policy interest rate. The unemployment rate gap is closely related through Okun's law. ${ }^{6}$ Orphanides and Williams (2005, 2006, and 2007) employ the unemployment rate gap in their models of central bank interest rate feedback rules.

Inflation, especially at higher levels, is associated with the economic state by depressing economic activity. In the stochastic discount factor (SDF) approach to exchange rates, the real depreciation is the foreign-U.S. difference in log real SDFs $\left(m_{t}\right), \Delta q_{i, t}=m_{i, t}-m_{0, t}$.

\footnotetext{
${ }^{6}$ Okun's law states that a one percent increase in the unemployment rate gap results in a two percent decline in the output gap.
} 
We try to obtain information on the international distribution of the log SDFs through consideration of the real exchange rate gap.

For each country, we compute time-varying conditional mean, conditional volatility, and conditional skewness of the macro variables. The conditional moments are estimated by sample moments computed from a backward-looking moving 18 -quarter window. ${ }^{7}$ We then form high-minus-low conditional mean $\left(\mathrm{HML}_{\text {mean }}\right)$, high-minus-low conditional volatility $\left(\mathrm{HML}_{v o l}\right)$, and high-minus-low conditional skewness $\left(\mathrm{HML}_{\text {skew }}\right)$ versions of these variables by subtracting the average value in the bottom quartile from the average in the top quartile.

We consider volatility since it is a popular measure of uncertainty. The skewness measure provides an alternative measure of macroeconomic uncertainty and highlights the role of distributional asymmetries. High (low) skewness means a high probability of a right (left) tail event. The high-minus-low construction is similar to the interquartile range, which captures the concept of global uncertainty. ${ }^{8}$ Our primary interest is in the higherordered moments (volatility and skewness), but Menkhoff et. al (2013) found first-moments to be priced, so we include them for comparison.

\section{Empirical Results}

We study systematic macroeconomic risk in carry-trade-generated excess returns by estimating the beta-risk model using the two-pass procedure. Let $\left\{r_{i, t}^{e}\right\}$, where $i=1, \ldots N$ and $t=1, \ldots, T$, denote our collection of $N=6$ portfolios of carry-trade excess returns. Let $\left\{f_{k, t}^{H M L}\right\}$, where $k=1, . ., K$, be a collection of potential $\mathrm{HML}_{\text {mean }}, \mathrm{HML}_{\text {vol }}$, and $\mathrm{HML}_{\text {skew }}$ macro risk factors. In the first pass, we run $N=6$ individual time-series regressions of the

\footnotetext{
${ }^{7}$ We also considered using a 16-quarter and a 20-quarter window. The results are robust to these alternative window lengths. These results are reported in Appendix C.

${ }^{8} \mathrm{We}$ point out that there is a literature that attempts to measure macroeconomic uncertainty. For example, Baker et al. (2016) build their measure by counting the frequency with which newspaper articles mention words like 'policy uncertainty,' and Jurado et al. (2013) which is based on the conditional volatility of forecast errors. In contrast, our measures are comparatively low tech and easily computable.
} 
excess returns on the factors to estimate the factor betas,

$$
r_{i, t}^{e}=a_{i}+\sum_{k=1}^{K} \beta_{i, k} f_{k, t}^{H M L}+\epsilon_{i, t} .
$$

The second pass is the single cross-sectional regression of the (time-series) mean excess returns on the estimated betas,

$$
\bar{r}_{i}^{e}=\gamma+\sum_{k=1}^{K} \lambda_{k} \beta_{i, k}+\alpha_{i}
$$

where $\bar{r}_{i}^{e}=(1 / T) \sum_{t=1}^{T} r_{i t}^{e}$ and the slope coefficient $\lambda_{k}$ is the risk premia associated with the $k-t h$ risk factor. We draw inference about the $\lambda s$ from generalized method of moments (GMM) standard errors as described in Cochrane (2005) and Burnside (2011b). GMM standard errors recognize that the betas in equation (5) are not themselves data, but are estimated from the data. They also account for potential serial correlation and heteroskedasticity in the errors. ${ }^{9}$

We begin with estimation of a single-factor model $(K=1)$, where the single risk factor is one of the $\mathrm{HML}_{\text {mean }}, \mathrm{HML}_{\text {vol }}$, and $\mathrm{HML}_{\text {skew }}$ global macro risk factors discussed above. Table 1 shows the second stage estimation results for the single-factor model. ${ }^{10}$ We see that the $\mathrm{HML}_{\text {skew }}$ of the unemployment gap factor is priced in the excess returns. The price of risk $\lambda$ is positive, the t-ratio is significant, and the $R^{2}$ is very high. Several other factor candidates also appear to be priced, such as $\mathrm{HML}_{\text {skew }}$ measures of $\Delta U E$ and $\Delta y, \mathrm{HML}_{v o l}$ measures of $\Delta U E, y^{g a p}, \Delta y, q^{g a p}, \Delta c$, and $\pi$, and $\mathrm{HML}_{\text {mean }}$ measures of $\Delta y, q^{g a p}, \Delta q$, and $\pi$. For these factor candidates, the t-ratios on $\lambda$ estimates are significant at the $5 \%$ level, and many of the $R^{2}$ values are also quite high. However, it is not the case that generically

\footnotetext{
${ }^{9}$ Details of the GMM estimation and inference are given in Appendix B.

${ }^{10}$ Note that construction of the factors requires 18 start-up observations. Estimation uses observations from 1977Q3-2014Q2.
} 
formed high-minus-low specifications on conditional moments of macro fundamentals will automatically get priced. For example, the $\mathrm{HML}_{\text {skew }}$ measures of the real exchange rate gap and real exchange rate changes are not priced, and these specifications have low $R^{2}$ values. ${ }^{11}$

The single-factor results give an informal impression that the $\mathrm{HML}_{\text {skew }}$ of the unemployment gap factor dominates the alternative measures of the global risk factor. The price of risk has the highest t-ratio and the regression has the highest $R^{2}$. Figure 1 displays the scatter plot of the average portfolio currency excess returns against the $\mathrm{HML}_{\text {skew }}$ of the unemployment gap betas multiplied by lambda.

To more formally assess the impression that $\mathrm{HML}_{\text {skew }}$ of the unemployment gap dominates, we estimate a series of two-factor models with the $\mathrm{HML}_{\text {skew }}$ of the unemployment gap as the maintained (first) factor and each of the alternative factor constructions as the second factor. Table 2 shows the two-factor estimation results.

Here, the $\mathrm{HML}_{\text {skew }}$ of the unemployment gap factor is significantly priced at the $5 \%$ level in all cases, while only $\mathrm{HML}_{v o l}$ of inflation and $\mathrm{HML}_{\text {mean }}$ of inflation are significantly priced as a second factor at the $5 \%$ level. We continue to find the Wald test on the pricing errors to be insignificant. These results provide additional support that the $\mathrm{HML}_{\text {skew }}$ of the unemployment gap factor is the global macro risk factor for carry trade excess returns.

\footnotetext{
${ }^{11}$ In closed-economy asset pricing, the excess return is constructed relative to what the investor considers to be the risk-free interest rate and if the model is properly specified, the intercept $\gamma$ should be zero. In the international setting, the carry trades are available to investors all around the world. When the trade matures, the payoff needs to be repatriated to the investor's home currency, which entails some foreign exchange risk. Hence, the excess returns relative to the U.S. are not necessarily relative to 'the' risk-free rate, so there is no presumption that the intercept $\gamma$ is zero.
} 
Table 1: Two-Pass Estimation of the Single-Factor Beta-Risk Model on Carry Excess Returns, 1977Q3-2014Q2

\begin{tabular}{|c|c|c|c|c|c|c|c|c|c|c|c|c|}
\hline Factor & $\lambda_{\text {skew }}$ & $\gamma$ & $R^{2}$ & $\begin{array}{r}\text { Test- } \\
\text { stat }\end{array}$ & $\lambda_{v o l}$ & $\gamma$ & $R^{2}$ & $\begin{array}{r}\text { Test- } \\
\text { stat }\end{array}$ & $\lambda_{\text {mean }}$ & $\gamma$ & $R^{2}$ & $\begin{array}{r}\text { Test- } \\
\text { stat }\end{array}$ \\
\hline \multirow[t]{2}{*}{$U E^{g a p}$} & 0.530 & $4.189^{*}$ & 0.972 & 0.763 & 0.620 & 2.477 & 0.009 & 10.195 & $3.837^{*}$ & 0.843 & 0.771 & 5.882 \\
\hline & [3.299] & {$[1.887]$} & & $(0.979)$ & {$[0.553]$} & [1.330] & & $(0.070)$ & [1.851] & {$[0.250]$} & & $(0.318)$ \\
\hline \multirow[t]{2}{*}{$\Delta U E$} & 0.590 & 2.612 & 0.780 & 3.095 & -0.066 & 2.402 & 0.133 & 7.725 & $0.086^{*}$ & -1.253 & 0.674 & 6.030 \\
\hline & {$[2.060]$} & {$[0.813]$} & & $(0.685)$ & [-1.998] & [1.059] & & $(0.172)$ & [1.915] & {$[-0.425]$} & & $(0.303)$ \\
\hline \multirow[t]{2}{*}{$y^{g a p}$} & 0.964 & 6.812 & 0.779 & 1.645 & 0.831 & -0.457 & 0.729 & 4.692 & $0.719 *$ & 0.450 & 0.688 & 6.157 \\
\hline & {$[1.236]$} & [1.003] & & $(0.896)$ & {$[2.341]$} & {$[-0.167]$} & & $(0.455)$ & [1.923] & {$[0.158]$} & & $(0.291)$ \\
\hline \multirow[t]{2}{*}{$\Delta y$} & 0.489 & 5.874 & 0.510 & 4.825 & 1.426 & -0.250 & 0.737 & 5.525 & -2.322 & 5.033 & 0.421 & 3.566 \\
\hline & [2.833] & [2.104] & & $(0.438)$ & [2.320] & {$[-0.111]$} & & $(0.355)$ & {$[-2.300]$} & [1.594] & & $(0.613)$ \\
\hline \multirow[t]{2}{*}{$q^{g a p}$} & -0.480 & -0.073 & 0.200 & 7.187 & 4.088 & 1.053 & 0.884 & 3.789 & 1.720 & 3.486 & 0.559 & 4.353 \\
\hline & {$[-1.306]$} & {$[-0.026]$} & & $(0.207)$ & [2.688] & {$[0.415]$} & & $(0.580)$ & [2.378] & {$[1.120]$} & & $(0.500)$ \\
\hline \multirow[t]{2}{*}{$\Delta q$} & 0.340 & 3.875 & 0.022 & 10.818 & $15.463^{*}$ & 5.668 & 0.783 & 3.039 & 2.042 & 0.962 & 0.382 & 8.176 \\
\hline & {$[1.255]$} & {$[2.136]$} & & $(0.055)$ & [1.920] & [1.375] & & $(0.694)$ & {$[2.100]$} & {$[0.464]$} & & $(0.147)$ \\
\hline \multirow[t]{2}{*}{$\Delta c$} & 0.429 & 2.389 & 0.431 & 4.659 & 1.340 & -1.403 & 0.863 & 4.775 & $-2.490^{*}$ & 5.703 & 0.658 & 2.266 \\
\hline & [1.439] & {$[0.786]$} & & $(0.459)$ & {$[2.577]$} & {$[-0.526]$} & & $(0.444)$ & {$[-1.889]$} & {$[1.132]$} & & $(0.811)$ \\
\hline \multirow[t]{2}{*}{$\pi$} & $-0.370^{*}$ & 6.468 & 0.136 & 4.323 & 2.699 & 0.445 & 0.624 & 6.529 & 7.526 & 1.555 & 0.745 & 5.495 \\
\hline & {$[-1.688]$} & [2.324] & & $(0.504)$ & {$[2.351]$} & {$[0.201]$} & & $(0.258)$ & [2.662] & {$[0.766]$} & & $(0.358)$ \\
\hline
\end{tabular}

Notes: The raw data are quarterly (1973Q1 to 2014Q2) and, when available, are end-of-quarter and point-sampled. 18-quarters start-up to compute initial high-minus-low factors. Model estimated on returns from 1977Q3 to 2014Q2. $\Delta y, y^{g a p}, \Delta c, \Delta U E$, $U E^{g a p}, \pi, q^{g a p}$, and $\Delta q$ represent the GDP growth rate, GDP gap, consumption growth rate, change in the unemployment rate, unemployment rate gap, inflation rate, real exchange rate gap, and real exchange rate depreciation, respectively. For each country (41 countries plus the euro area) and each macroeconomic variable, we compute the 'conditional' mean, volatility, and skewness using an 18-quarter window. To form the portfolio returns, we sort by the nominal interest rate (carry) for each country from low to high. The rank ordering is divided into six portfolios, into which the currency returns are assigned. $P_{6}$ is the portfolio of returns associated with the highest nominal interest rate countries and $P_{1}$ is the portfolio of returns associated with the lowest nominal interest rate countries. This table reports the two-pass procedure estimation results from a one-factor model. In the first pass, we run $N=6$ individual time-series regressions of the excess returns on the $K$ factors to estimate the factor 'betas,' $r_{i, t}^{e}=a_{i}+\sum_{k=1}^{K} \beta_{i, k} f_{k, t}^{H M L}+\epsilon_{i, t}$, where $r_{i, t}^{e}$ is the excess return, $\beta_{i, k}$ is the factor beta, and $f_{k, t}^{H M L}$ is the high-minus-low $\left(\mathrm{HML}_{\text {mean }}, \mathrm{HML}_{\text {vol }}\right.$, or $\mathrm{HML}_{\text {skew }}$ ) macro risk factor. The factors considered include the high-minus-low values of the conditional mean, volatility, and skewness of $\Delta y, y^{g a p}, \Delta c, \Delta U E, U E^{g a p}, \pi, q^{g a p}$, and $\Delta q$. Each high-minus-low value is equal to the average in the highest quartile minus the average in the lowest quartile. In the second pass, we run a single cross-sectional regression of the (time-series) mean excess returns on the estimated betas, $\bar{r}_{i}^{e}=\gamma+\sum_{k=1}^{K} \lambda_{k} \beta_{i, k}+\alpha_{i}$, where $\bar{r}_{i}^{e}$ is the average excess return, $\gamma$ is the intercept, $\lambda_{k}$ is the risk premia, and $\alpha_{i}$ is the pricing error. The table reports the price of risk $(\lambda)$ and its associated t-ratio (using GMM standard errors) in brackets, the estimated intercept $(\gamma)$ and its associate t-ratio in brackets, the Wald test on the pricing errors (Test-stat) and its associated p-value in parentheses, and $R^{2}$. Bold indicates significance at the $5 \%$ level. '*' indicates significance at the $10 \%$ level. 
Figure 1: Average Excess Returns and $\beta \lambda$ from the $H M L_{\text {skew }}$ of the $U E^{\text {gap }}$ Beta-Risk Model, 1977Q3-2014Q2

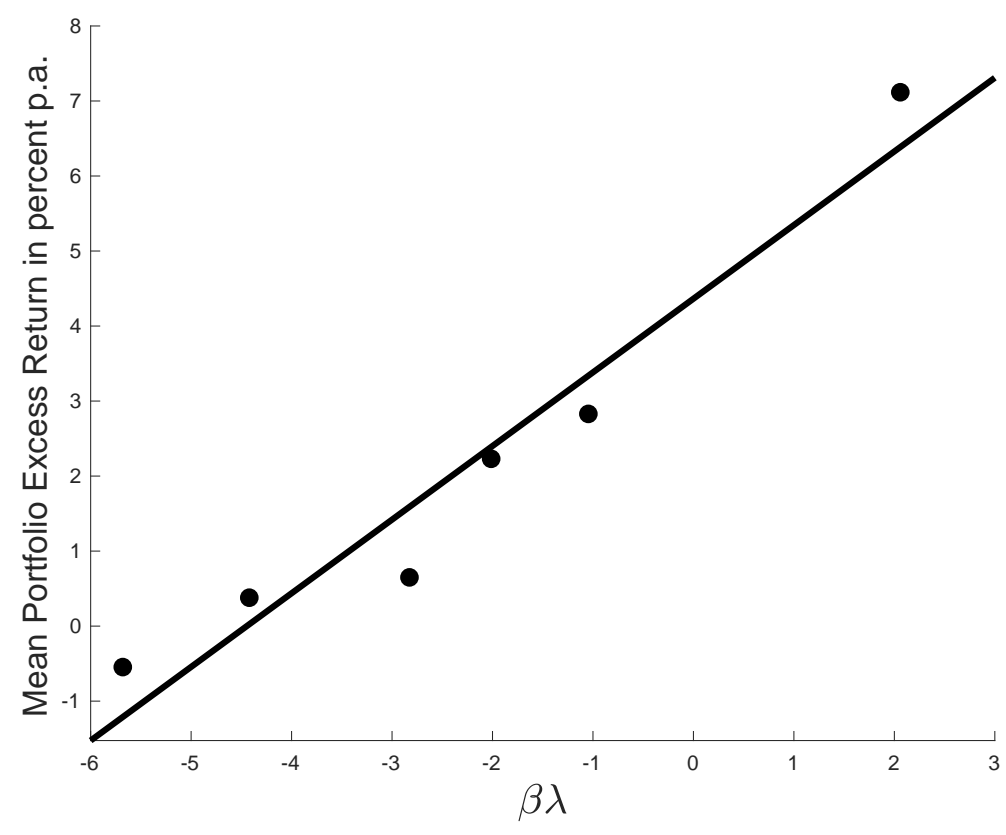

Notes: The raw data are quarterly (1973Q1 to 2014Q2) and, when available, are end-of-quarter and pointsampled. For each country (41 countries plus the euro area), we compute the 'conditional' unemployment rate gap skewness using an 18-quarter window. To form the portfolio returns, we sort by the nominal interest rate for each country from low to high. The rank ordering is divided into six categories, into which the currency returns are assigned. $P_{6}$ is the portfolio of returns associated with the highest interest rate quantile and $P_{1}$ is the portfolio of returns associated with the lowest interest rate quantile. The excess returns are the average of the USD returns in each category minus the U.S. nominal interest rate and are stated in percent per annum. The figure plots portfolio average excess returns against $\beta \lambda$. 
Table 2: Two-Pass Estimation of the Two-Factor Beta-Risk Model on Carry Excess Returns, 1977Q3-2014Q2

\begin{tabular}{|c|c|c|c|c|c|c|c|c|c|c|c|c|c|c|c|}
\hline Factor & $\lambda_{1}$ & $\lambda_{\text {skew }}$ & $\gamma$ & $R^{2}$ & $\begin{array}{r}\text { Test- } \\
\text { stat }\end{array}$ & $\lambda_{1}$ & $\lambda_{v o l}$ & $\gamma$ & $R^{2}$ & $\begin{array}{r}\text { Test- } \\
\text { stat }\end{array}$ & $\lambda_{1}$ & $\lambda_{\text {mean }}$ & $\gamma$ & $R^{2}$ & $\begin{array}{l}\text { Test- } \\
\text { stat }\end{array}$ \\
\hline \multirow[t]{2}{*}{$U E^{g a p}$} & - & - & - & - & - & 0.449 & -0.187 & 3.513 & 0.927 & 2.975 & 0.385 & 0.809 & 2.858 & 0.931 & 2.508 \\
\hline & - & - & - & - & - & [3.071] & {$[-0.147]$} & [1.432] & & $(0.704)$ & {$[2.007]$} & {$[0.451]$} & [1.185] & & $(0.775)$ \\
\hline \multirow[t]{2}{*}{$\Delta U E$} & 0.569 & 0.181 & $4.574^{*}$ & 0.988 & 0.321 & 0.516 & -0.021 & 3.437 & 0.952 & 1.866 & 0.459 & 0.008 & 2.756 & 0.958 & 1.342 \\
\hline & [3.124] & {$[0.622]$} & {$[1.752]$} & & $(0.997)$ & [3.111] & {$[-0.532]$} & {$[1.452]$} & & $(0.867)$ & {$[2.254]$} & {$[0.243]$} & {$[1.043]$} & & (0.931) \\
\hline \multirow[t]{2}{*}{$y^{g a p}$} & 0.523 & 0.465 & 5.077 & 0.995 & 0.071 & 0.414 & 0.424 & 2.347 & 0.955 & 1.459 & 0.452 & 0.256 & 3.097 & 0.930 & 2.613 \\
\hline & {$[2.755]$} & {$[0.961]$} & [1.391] & & $(1.000)$ & {$[2.730]$} & [1.466] & {$[0.933]$} & & $(0.918)$ & [2.533] & {$[0.793]$} & {$[1.223]$} & & $(0.759)$ \\
\hline \multirow[t]{2}{*}{$\Delta y$} & 0.503 & 0.232 & $4.918^{*}$ & 0.997 & 0.138 & 0.513 & 0.701 & 3.222 & 0.959 & 1.494 & 0.542 & -0.710 & 3.561 & 0.957 & 1.641 \\
\hline & [2.981] & [1.063] & {$[1.842]$} & & $(1.000)$ & [2.448] & [1.169] & {$[1.209]$} & & $(0.914)$ & [3.169] & {$[-0.803]$} & {$[1.445]$} & & $(0.896)$ \\
\hline \multirow[t]{2}{*}{$q^{g a p}$} & 0.557 & 0.177 & 5.237 & 0.990 & 0.481 & 0.422 & $2.538^{*}$ & 2.543 & 0.938 & 3.095 & 0.485 & 0.187 & 3.327 & 0.943 & 2.537 \\
\hline & [2.890] & {$[0.471]$} & [1.471] & & $(0.993)$ & [3.191] & [1.791] & [1.163] & & $(0.685)$ & [2.923] & [0.342] & {$[1.207]$} & & $(0.771)$ \\
\hline \multirow[t]{2}{*}{$\Delta q$} & 0.532 & 0.347 & 5.502 & 0.993 & 0.354 & 0.528 & 2.734 & 3.158 & 0.953 & 1.626 & 0.526 & 0.653 & 3.613 & 0.954 & 1.814 \\
\hline & [3.271] & {$[0.589]$} & {$[1.591]$} & & $(0.997)$ & {$[2.871]$} & {$[0.499]$} & {$[1.149]$} & & $(0.898)$ & {$[2.980]$} & {$[0.740]$} & {$[1.487]$} & & $(0.874)$ \\
\hline \multirow[t]{2}{*}{$\Delta c$} & 0.489 & 0.089 & $4.029^{*}$ & 0.984 & 0.528 & 0.489 & 0.627 & 2.804 & 0.960 & 1.814 & 0.545 & -0.440 & 3.458 & 0.957 & 1.571 \\
\hline & {$[2.606]$} & {$[0.397]$} & {$[1.912]$} & & $(0.991)$ & {$[2.052]$} & [1.175] & {$[0.834]$} & & $(0.874)$ & [2.992] & {$[-0.442]$} & {$[1.323]$} & & $(0.905)$ \\
\hline \multirow[t]{2}{*}{$\pi$} & 0.528 & -0.078 & 4.616 & 0.973 & 0.610 & 0.498 & 1.722 & 3.067 & 0.957 & 1.463 & 0.493 & 4.366 & 3.191 & 0.957 & 1.551 \\
\hline & [3.264] & {$[-0.399]$} & {$[1.629]$} & & $(0.988)$ & [3.006] & {$[2.155]$} & {$[1.332]$} & & $(0.917)$ & [2.957] & [2.015] & {$[1.468]$} & & $(0.907)$ \\
\hline
\end{tabular}

Notes: We estimate a two-factor model with the $\mathrm{HML}_{\text {skew }}$ of the $U E^{g a p}$ as the maintained first factor (associated with $\lambda_{1}$ ) and each of the alternative factor 
Table 3: Excess Return and Beta Decomposition, 1977Q3-2014Q2

\begin{tabular}{lrrrrrr}
\hline \hline & $P_{1}$ & $P_{2}$ & $P_{3}$ & $P_{4}$ & $P_{5}$ & $P_{6}$ \\
\hline Total Excess Return & -1.161 & -0.367 & 0.645 & 1.317 & 1.936 & 6.941 \\
$\beta$ & -9.941 & -7.509 & -5.126 & -3.074 & -2.462 & 5.785 \\
t-ratio & {$[-2.186]$} & {$[-1.834]$} & {$[-1.282]$} & {$[-0.724]$} & {$[-0.687]$} & {$[1.068]$} \\
& & & & & & \\
Interest Rate Differential & -2.916 & -1.055 & 0.669 & 2.326 & 4.871 & 16.464 \\
$\beta$ & -1.509 & -1.195 & -1.024 & -0.761 & 0.366 & 10.853 \\
t-ratio & {$[-1.223]$} & {$[-1.404]$} & {$[-1.560]$} & {$[-0.993]$} & {$[0.422]$} & {$[3.084]$} \\
& & & & & & \\
Exchange Rate Return & 1.755 & 0.688 & -0.024 & -1.008 & -2.934 & -9.523 \\
$\beta$ & -8.432 & -6.314 & -4.102 & -2.313 & -2.828 & -5.067 \\
t-ratio & {$[-1.849]$} & {$[-1.615]$} & {$[-1.132]$} & {$[-0.586]$} & {$[-0.754]$} & {$[-0.901]$} \\
\hline \hline
\end{tabular}

Notes: Currency excess returns are in log-units. The total excess return, interest rate differential, and exchange rate return $\beta$ s come from equations (6)-(8). The factor is $\mathrm{HML}_{\text {skew }}$ of the unemployment rate gap. t-ratios are computed by Newey-West and are in brackets.

Decomposition. To delve deeper into the risk-return relationship, Table 3 reports the decomposition of the betas of the portfolio excess returns in log-units into contributions from the interest rate differential and the exchange rate return components. ${ }^{12}$ The total excess return $\beta$ is from the regression

$$
r_{i, t}^{e}=a_{i}+\beta_{i} f_{t}^{H M L}+\epsilon_{i, t}
$$

the interest rate differential $\beta$ is from the regression

$$
\frac{1}{n_{i, t}} \sum_{j \in P_{i}}\left(r_{j, t-1}-r_{0, t-1}\right)=a_{i}+\beta_{i} f_{t}^{H M L}+\epsilon_{i, t},
$$

and the exchange rate return $\beta$ is from the regression

$$
\frac{1}{n_{i, t}} \sum_{j \in P_{i}} \Delta \ln \left(S_{j, t}\right)=a_{i}+\beta_{i} f_{t}^{H M L}+\epsilon_{i, t},
$$

\footnotetext{
${ }^{12}$ Statistical significance of the betas are not the key issue as the GMM standard error estimates on the $\lambda$ estimates take into account that the betas are estimated.
} 
where $i=1, \ldots, 6$ and $f_{t}^{H M L}$ is the $\mathrm{HML}_{\text {skew }}$ of the unemployment rate gap factor. Notice that the betas on exchange rate returns are uniformly negative. Currency values of all the portfolios decline relative to the USD in times when the factor is high. Similarly, the betas for the interest rate differentials for $P_{1}$ through $P_{4}$ are negative. However, the beta for the interest rate differentials for $P_{5}$ and $P_{6}$ are positive. For $P_{6}$, the magnitude is so large that it more than offsets the negative beta for the exchange rate return. Why do yields increase for these portfolios in times of high global uncertainty? Because global investors flee the debt of these countries in the bad state which drives bond prices down and yields up.

Factor Dynamics and Country Composition. A visual of the factor is presented in Figure 2, which plots the high, low, and high-minus-low average values of skewness of the unemployment rate gap. Low skewness is typically negative. The figure also shows Europe and U.S. business cycle dating.

Figure 2: High, Low, and High-Minus-Low Unemployment Rate Gap Skewness and U.S. and Europe Recession Dates

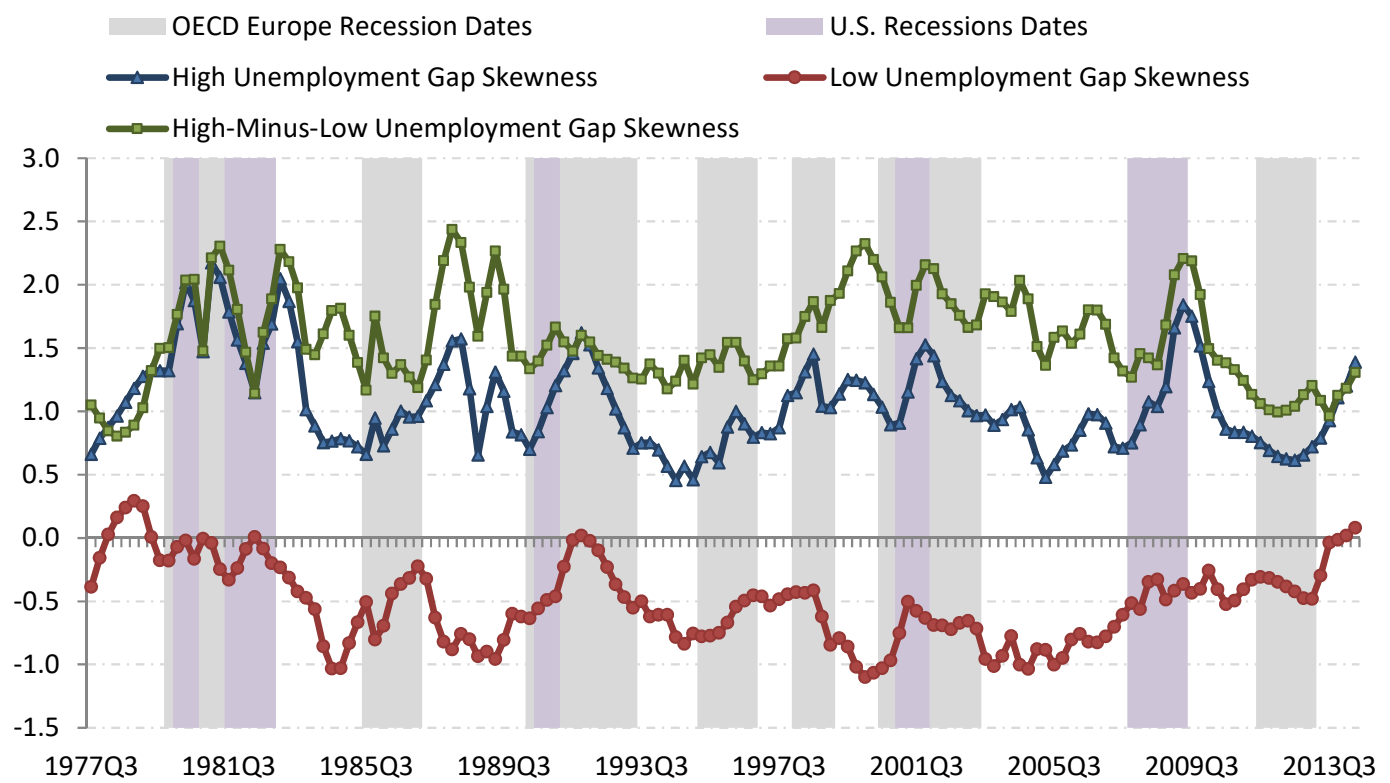

Notes: The raw data are quarterly (1973Q1 to 2014Q2). For each country (41 countries plus the euro area), we compute the 'conditional' unemployment rate gap skewness using an 18-quarter window. 
To see which countries are key in constructing the factor, Table 4 lists the top 10 countries that appear most frequently in construction of the $\mathrm{HML}_{\text {skew }}$ of the unemployment gap factor. They are roughly a mix of developed and emerging economies. In the carry trade, the Australian dollar is typically a long currency and the Japanese yen is typically a short currency. Consistent with this, Australia is featured in the top quartile of unemployment gap skewness $51 \%$ of the time and Japan is featured in the bottom quartile $26 \%$ percent of the time.

Table 4: Top 10 Countries that Appear Most Frequently in the High and Low Unemployment Rate Gap Skewness Categories

\begin{tabular}{lclc}
\hline \hline Country & $\begin{array}{c}\text { Proportion } \\
\text { of Times in } \\
\text { Top Quartile }\end{array}$ & Country & $\begin{array}{c}\text { Proportion } \\
\text { of Times in } \\
\text { Bottom Quartile }\end{array}$ \\
\hline Australia & 0.514 & Norway & 0.324 \\
Canada & 0.401 & United States & 0.303 \\
Taiwan & 0.296 & Denmark & 0.282 \\
Singapore & 0.275 & Japan & 0.261 \\
United States & 0.254 & New Zealand & 0.254 \\
Mexico & 0.239 & Mexico & 0.232 \\
Iceland & 0.232 & Canada & 0.211 \\
Switzerland & 0.232 & Italy & 0.197 \\
United Kingdom & 0.183 & Brazil & 0.190 \\
New Zealand & 0.183 & Switzerland & 0.190 \\
\hline \hline
\end{tabular}

Notes: The table shows the proportion of times the skewness of a country's unemployment rate gap is in the top quartile or in the bottom quartile from 1977Q3 to 2014Q2.

Relation of Factor to Other Uncertainty Measures. We interpret a high value of the factor to represent a high degree of global uncertainty, but is the $\mathrm{HML}_{\text {skew }}$ of the unemployment gap simply replicating other uncertainty measures proposed in the literature? We examine this question by regressing the factor on alternative news-based measures of economic uncertainty constructed by Baker et al. (2016). We consider the uncertainty indices for 
the U.S., Europe, Japan, Australia, and a global measure. ${ }^{13}$ We also regress the $\mathrm{HML}_{\text {skew }}$ of the unemployment gap on the log VIX and a log measure of U.S. financial uncertainty. Table 5 shows the results.

Table 5: Regressions of $\mathrm{HML}_{\text {skew }}$ of the $U E^{\text {gap }}$ on Alternative Uncertainty Measures

\begin{tabular}{lrrrr}
\hline \hline & & & & Sample \\
Variable & Coeff. & t-ratio & $R^{2}$ & Begins \\
\hline Log VIX & $\mathbf{0 . 2 7 2}$ & {$[2.433]$} & 0.067 & $1990 \mathrm{Q} 1$ \\
Log U.S. Finance & 0.353 & {$[1.538]$} & 0.037 & $1985 \mathrm{Q} 1$ \\
Log U.S. EPU & -0.075 & {$[-1.072]$} & 0.018 & $1978 \mathrm{Q} 1$ \\
Log Europe EPU & $\mathbf{- 0 . 4 6 7}$ & {$[-2.966]$} & 0.191 & $1987 \mathrm{Q} 1$ \\
Log Global EPU & $\mathbf{- 0 . 2 6 8}$ & {$[-2.612]$} & 0.145 & $1978 \mathrm{Q} 1$ \\
Log Japan EPU & $\mathbf{- 0 . 2 7 6}$ & {$[-2.084]$} & 0.099 & $1988 \mathrm{Q} 2$ \\
Log Australia EPU & $\mathbf{- 0 . 6 1 3}$ & {$[-3.506]$} & 0.182 & $1998 \mathrm{Q} 1$ \\
\hline \hline
\end{tabular}

Notes: Bold indicates significance at the $5 \%$ level. Log U.S., Europe, Japan, Australia, Global Uncertainty, and U.S. Finance indices are from Baker et al. (2016) which were downloaded from their website, http://www.policyuncertainty.com/index.html. They are indices built from the frequency of words appearing in major newspapers that refer to economic or policy uncertainty. The VIX is the Chicago Board of Options Exchange volatility index.

Our proposed factor is negatively correlated with the news-based measures of uncertainty and the regression $R^{2}$ are quite low. Although the slope on the log VIX is positive and significant, the $R^{2}$ on this regression is also very small. Our factor is also positively correlated with the U.S. financial uncertainty index, but the slope is not significant. The information content in the $\mathrm{HML}_{\text {skew }}$ of the unemployment gap variable is very different from that contained in these more popular measures of uncertainty.

Predictive Value. The factor is constructed by conditioning on past observations. Does this formulation of the past have predictive value? To examine this issue, we regress the crosssectional mean of interest rates and consumption growth, and the cross-sectional standard deviation of interest rates and consumption growth on one lagged value of the factor.

\footnotetext{
${ }^{13}$ Baker et al. (2016) create uncertainty indices for Australia, China, Europe, France, Germany, Great Britain, India, Italy, Japan, Korea, Russia, Spain, and the United States. We form the global index by taking the cross-sectional average of the individual country indices.
} 
Table 6 shows the results. These in-sample predictive regressions show support that the factor has predictive power for the cross-sectional mean of interest rates, the cross-sectional volatility of interest rates and the cross-sectional volatility of consumption growth.

\begin{tabular}{lrrrr} 
Table 6: & Predictive value of $\mathrm{HML}_{\text {skew }}$ of the $U E^{\text {gap }}$ \\
\hline \hline & \multicolumn{2}{c}{ Interest Rate } & \multicolumn{2}{c}{ Consumption Growth } \\
& \multicolumn{2}{c}{ Cross-sectional } & \multicolumn{2}{c}{ Cross-sectional } \\
& Mean & Volatility & Mean & Volatility \\
\hline Coeff. & $\mathbf{2 . 7 4 0}$ & $\mathbf{3 . 3 2 9}$ & 0.056 & $\mathbf{0 . 4 3 9}$ \\
t-ratio & {$[1.988]$} & {$[2.143]$} & {$[0.114]$} & {$[2.384]$} \\
$R^{2}$ & 0.073 & 0.048 & 0.000 & 0.052 \\
\hline \hline
\end{tabular}

Notes: Regression of the cross-sectional mean (cross-sectional volatility) on lagged $\mathrm{HML}_{\text {skew }}$ of the $U E^{\text {gap }}$.

Why might a higher value of the factor predict increased international dispersion of interest rates and consumption growth? A potential channel is if there are heterogeneous responses by central bankers across countries to the unemployment gap in conducting monetary policy. When global economic uncertainty rises, country policy rates react differently. Investors flee the debt of risky countries and households adjust consumption differentially as well, which generates higher cross-sectional average interest rates and higher cross-sectional volatility of interest rates and consumption growth.

Pre-Crisis Sample. Since we are using quarterly observations due to the availability of the macro variables, we do not have a surplus of time-series observations. Nevertheless, we can do some limited subsample analyses. Here, we ask if our results are driven by the global financial crisis. Lustig and Verdelhan (2011) point specifically to the poor performance of the carry trade during the crisis as an example of the risk borne by international investors in the carry trade. To answer this question, we end the sample in 2008Q2. 
Table 7: Pre-Crisis Two-Pass Estimation of the Single-Factor Beta-Risk Model on Carry Excess Returns, 1977Q3-2008Q2

\begin{tabular}{|c|c|c|c|c|c|c|c|c|c|c|c|c|}
\hline Factor & $\lambda_{\text {skew }}$ & $\gamma$ & $R^{2}$ & $\begin{array}{r}\text { Test- } \\
\text { stat }\end{array}$ & $\lambda_{v o l}$ & $\gamma$ & $R^{2}$ & $\begin{array}{r}\text { Test- } \\
\text { stat }\end{array}$ & $\lambda_{\text {mean }}$ & $\gamma$ & $R^{2}$ & $\begin{array}{r}\text { Test- } \\
\text { stat }\end{array}$ \\
\hline \multirow{2}{*}{$\overline{U E^{g a p}}$} & 0.597 & 6.613 & 0.954 & 0.540 & 1.439 & 3.111 & 0.042 & 9.234 & 4.359 & 0.649 & 0.780 & 4.555 \\
\hline & [2.403] & [2.215] & & (0.991) & {$[0.869]$} & {$[1.228]$} & & $(0.100)$ & [1.568] & {$[0.146]$} & & $(0.473)$ \\
\hline \multirow[t]{2}{*}{$\Delta U E$} & 0.670 & 3.815 & 0.746 & 2.057 & $-0.068^{*}$ & 2.484 & 0.103 & 7.657 & $0.088^{*}$ & -1.071 & 0.681 & 5.887 \\
\hline & [1.541] & {$[0.874]$} & & $(0.841)$ & {$[-1.671]$} & [0.900] & & $(0.176)$ & [1.771] & {$[-0.307]$} & & $(0.317)$ \\
\hline \multirow[t]{2}{*}{$y^{g a p}$} & 1.078 & 6.245 & 0.960 & 0.522 & 0.876 & 0.344 & 0.701 & 4.178 & 0.792 & 0.460 & 0.659 & 6.148 \\
\hline & {$[0.924]$} & [0.671] & & (0.991) & [2.017] & [0.101] & & $(0.524)$ & [1.568] & {$[0.118]$} & & $(0.292)$ \\
\hline \multirow[t]{2}{*}{$\Delta y$} & 0.509 & 5.534 & 0.608 & 3.093 & 1.392 & 0.374 & 0.727 & 5.104 & -1.856 & 4.691 & 0.221 & 4.926 \\
\hline & {$[2.310]$} & {$[1.516]$} & & $(0.686)$ & [2.041] & {$[0.143]$} & & $(0.403)$ & {$[-2.026]$} & [1.430] & & $(0.425)$ \\
\hline \multirow[t]{2}{*}{$q^{g a p}$} & -0.313 & 0.941 & 0.054 & 7.664 & $4.980^{*}$ & 1.360 & 0.850 & 2.018 & 1.842 & 4.962 & 0.362 & 3.550 \\
\hline & {$[-0.864]$} & {$[0.280]$} & & $(0.176)$ & [1.934] & {$[0.320]$} & & $(0.847)$ & [2.175] & {$[1.141]$} & & $(0.616)$ \\
\hline \multirow[t]{2}{*}{$\Delta q$} & -0.258 & 1.628 & 0.011 & 10.125 & 18.610 & 8.666 & 0.614 & 2.049 & $2.194^{*}$ & 0.499 & 0.310 & 6.848 \\
\hline & {$[-0.515]$} & [0.503] & & $(0.072)$ & [1.481] & [1.398] & & $(0.842)$ & {$[1.701]$} & {$[0.176]$} & & $(0.232)$ \\
\hline \multirow[t]{2}{*}{$\Delta c$} & 0.418 & 0.981 & 0.585 & 3.366 & 1.027 & -0.354 & 0.864 & 3.792 & $-1.814^{*}$ & 6.148 & 0.269 & 3.322 \\
\hline & [1.237] & [0.263] & & $(0.644)$ & [2.589] & {$[-0.132]$} & & $(0.580)$ & {$[-1.730]$} & {$[1.221]$} & & $(0.651)$ \\
\hline \multirow[t]{2}{*}{$\pi$} & -0.276 & 5.479 & 0.110 & 4.593 & $2.536^{*}$ & 0.301 & 0.545 & 5.496 & $7.238^{*}$ & 1.827 & 0.699 & 3.304 \\
\hline & {$[-1.496]$} & [2.047] & & $(0.468)$ & [1.697] & [0.091] & & $(0.358)$ & [1.773] & {$[0.607]$} & & $(0.653)$ \\
\hline
\end{tabular}

Notes: See notes to Table 1.

Table 7 shows the results from the single-factor estimation over the pre-crisis sample. The $\mathrm{HML}_{\text {skew }}$ of the unemployment gap factor remains significantly priced at the $5 \%$ level and gives the second highest $R^{2}$. In the specification with the highest $R^{2}$, the macro risk factor is not significant. Fewer of the alternative factor measures are significantly priced. This could be because they were more pronounced during the crisis or because we have a smaller sample, having lost 24 quarterly observations-a reduction of $16 \%$ of the time-series observations.

In Table 8, we evaluate robustness in the pre-crisis subsample, by maintaining $\mathrm{HML}_{\text {skew }}$ of the unemployment gap as the first factor and alternating the second factor. $\mathrm{HML}_{\text {skew }}$ of the unemployment gap remains significantly priced at the $5 \%$ level in 14 specifications and at the $10 \%$ level in 4 specifications. The only alternative factor that is significantly priced at the $5 \%$ level is the $\mathrm{HML}_{v o l}$ of consumption growth. 
Table 8: Pre-Crisis Two-Pass Estimation of the Two-Factor Beta-Risk Model on Carry Excess Returns, 1977Q3-2008Q2

\begin{tabular}{|c|c|c|c|c|c|c|c|c|c|c|c|c|c|c|c|}
\hline Factor & $\lambda_{1}$ & $\lambda_{\text {skew }}$ & $\gamma$ & $R^{2}$ & $\begin{array}{r}\text { Test- } \\
\text { stat }\end{array}$ & $\lambda_{1}$ & $\lambda_{v o l}$ & $\gamma$ & $R^{2}$ & $\begin{array}{r}\text { Test- } \\
\text { stat }\end{array}$ & $\lambda_{1}$ & $\lambda_{\text {mean }}$ & $\gamma$ & $R^{2}$ & $\begin{array}{r}\text { Test- } \\
\text { stat }\end{array}$ \\
\hline \multirow{2}{*}{$U E^{g a p}$} & - & - & - & - & - & 0.509 & -0.047 & 6.227 & 0.867 & 2.428 & 0.347 & 1.302 & 4.210 & 0.894 & 2.785 \\
\hline & - & - & - & - & - & {$[2.243]$} & {$[-0.021]$} & [1.595] & & $(0.787)$ & [1.297] & {$[0.478]$} & {$[1.152]$} & & $(0.733)$ \\
\hline \multirow[t]{2}{*}{$\Delta U E$} & 0.647 & 0.218 & $7.426^{*}$ & 0.979 & 0.221 & 0.615 & -0.026 & 6.118 & 0.922 & 1.324 & 0.517 & 0.014 & 4.751 & 0.935 & 1.105 \\
\hline & {$[2.237]$} & {$[0.476]$} & {$[1.877]$} & & $(0.999)$ & {$[2.184]$} & {$[-0.364]$} & {$[1.642]$} & & $(0.932)$ & {$[1.572]$} & {$[0.287]$} & {$[1.190]$} & & $(0.954)$ \\
\hline \multirow[t]{2}{*}{$y^{g a p}$} & 0.507 & 0.713 & 6.541 & 0.989 & 0.110 & 0.440 & 0.633 & 4.270 & 0.907 & 1.700 & $0.460^{*}$ & 0.292 & 5.061 & 0.871 & 2.973 \\
\hline & {$[1.239]$} & {$[0.520]$} & {$[1.163]$} & & $(1.000)$ & {$[2.086]$} & {$[1.486]$} & {$[1.165]$} & & $(0.889)$ & {$[1.755]$} & {$[0.555]$} & {$[1.292]$} & & $(0.704)$ \\
\hline \multirow[t]{2}{*}{$\Delta y$} & $0.539^{*}$ & 0.263 & 6.871 & 0.990 & 0.324 & $0.577^{*}$ & 1.259 & 5.504 & 0.925 & 1.211 & 0.615 & -0.804 & $6.134^{*}$ & 0.922 & 1.326 \\
\hline & [1.889] & {$[0.878]$} & [2.385] & & (0.997) & [1.705] & {$[1.592]$} & [1.335] & & $(0.944)$ & [2.171] & {$[-0.604]$} & {$[1.802]$} & & $(0.932)$ \\
\hline \multirow[t]{2}{*}{$q^{g a p}$} & 0.663 & 0.326 & 8.520 & 0.989 & 0.304 & 0.451 & 3.289 & 3.949 & 0.888 & 2.289 & 0.547 & 0.125 & 5.943 & 0.886 & 2.249 \\
\hline & [2.134] & {$[0.552]$} & {$[1.567]$} & & $(0.998)$ & {$[2.266]$} & [1.309] & [1.006] & & $(0.808)$ & {$[2.077]$} & {$[0.150]$} & {$[1.340]$} & & $(0.814)$ \\
\hline \multirow[t]{2}{*}{$\Delta q$} & 0.605 & 0.345 & 8.785 & 0.988 & 0.333 & $0.638^{*}$ & 0.848 & 5.059 & 0.934 & 0.883 & 0.630 & 0.507 & $6.442^{*}$ & 0.923 & 1.273 \\
\hline & {$[2.305]$} & {$[0.360]$} & {$[1.486]$} & & $(0.997)$ & {$[1.861]$} & [0.093] & {$[1.147]$} & & $(0.971)$ & {$[2.043]$} & {$[0.331]$} & {$[1.800]$} & & $(0.938)$ \\
\hline \multirow[t]{2}{*}{$\Delta c$} & 0.532 & 0.065 & $5.877^{*}$ & 0.964 & 0.544 & 0.508 & 1.028 & 4.249 & 0.933 & 1.378 & 0.620 & -0.227 & 5.813 & 0.924 & 1.156 \\
\hline & {$[1.564]$} & {$[0.210]$} & {$[1.842]$} & & $(0.990)$ & {$[1.465]$} & {$[2.241]$} & {$[0.855]$} & & $(0.927)$ & {$[2.006]$} & {$[-0.186]$} & {$[1.580]$} & & $(0.949)$ \\
\hline \multirow[t]{2}{*}{$\pi$} & 0.596 & -0.028 & 6.678 & 0.954 & 0.495 & 0.589 & 1.773 & 5.453 & 0.928 & 1.046 & 0.583 & 4.375 & $5.625^{*}$ & 0.926 & 1.047 \\
\hline & [2.365] & {$[-0.110]$} & {$[2.119]$} & & $(0.992)$ & [2.063] & {$[1.520]$} & [1.507] & & (0.959) & [1.963] & [1.319] & [1.673] & & $(0.959)$ \\
\hline
\end{tabular}

Notes: See notes to Table 1 and Table 2. 
Sorting currency excess returns by beta. In the foregoing analysis, we sorted countries into portfolios and found that their excess returns varied proportionately with their betas on the $\mathrm{HML}_{\text {skew }}$ of the unemployment gap factor. Additional evidence that this variable provides a risk-based explanation would be if the betas of individual excess returns vary and are increasing in those returns. To investigate along these lines, for each individual currency $i$, at time $t$, we create an excess return by going long (short) in that currency if its interest rate is higher (lower) than the U.S. interest rate. We then estimate beta for each currency individually and sort the excess returns into three portfolios by their beta.

Table 9: Low- and High-Beta Countries, 1977Q3-2014Q2

\begin{tabular}{lrr|lrr}
\hline \hline & \multicolumn{3}{l|}{ First Tertile } & \multicolumn{3}{c}{ Third Tertile } \\
Country & $\beta$ & Excess Return & Country & $\beta$ & Excess Return \\
\hline Portugal & -46.182 & 0.957 & Hungary & 10.907 & 5.327 \\
Greece & -18.531 & 1.298 & Netherlands & 12.961 & 2.599 \\
Italy & -18.129 & 1.395 & Mexico & 13.828 & 3.509 \\
Denmark & -15.340 & 7.181 & Czech Republic & 13.829 & 3.627 \\
Spain & -14.287 & 3.462 & Ireland & 14.116 & -0.218 \\
France & -13.372 & 4.964 & Europe & 14.892 & 2.798 \\
Finland & -10.125 & 3.686 & Germany & 16.288 & 1.331 \\
Austria & -9.796 & 5.988 & Chile & 18.300 & 3.414 \\
Taiwan & -2.411 & -0.236 & Romania & 20.108 & 10.941 \\
Sweden & -2.075 & 6.179 & Turkey & 25.641 & 17.598 \\
Israel & -1.146 & 1.580 & Indonesia & 26.577 & 4.818 \\
Philippines & -0.876 & 3.010 & Colombia & 34.460 & 18.066 \\
New Zealand & -0.442 & 5.054 & Brazil & 35.479 & 11.837 \\
\hline Average & -11.747 & 3.117 & Average & 19.799 & 6.588 \\
\hline \hline
\end{tabular}

Notes: First and third tertile $\mathrm{HML}_{\text {skew }}$ of the unemployment rate gap betas on individual currency excess returns and their average excess return.

Table 9 shows the individual country betas and excess returns associated with the low and high tertile beta countries. Looking at individual currency excess returns reveals there are both positive beta and negative beta currencies. The identification by individual country, while not exact, shows a clear tendency for excess returns to be correlated with 
betas.

On the left in Figure 3, we see the scatter plot for all of the currency excess returns against their betas. In the right figure, we eliminate those European countries that adopted the euro when they entered the currency union.

Figure 3: Individual Country Mean Excess Returns and Betas
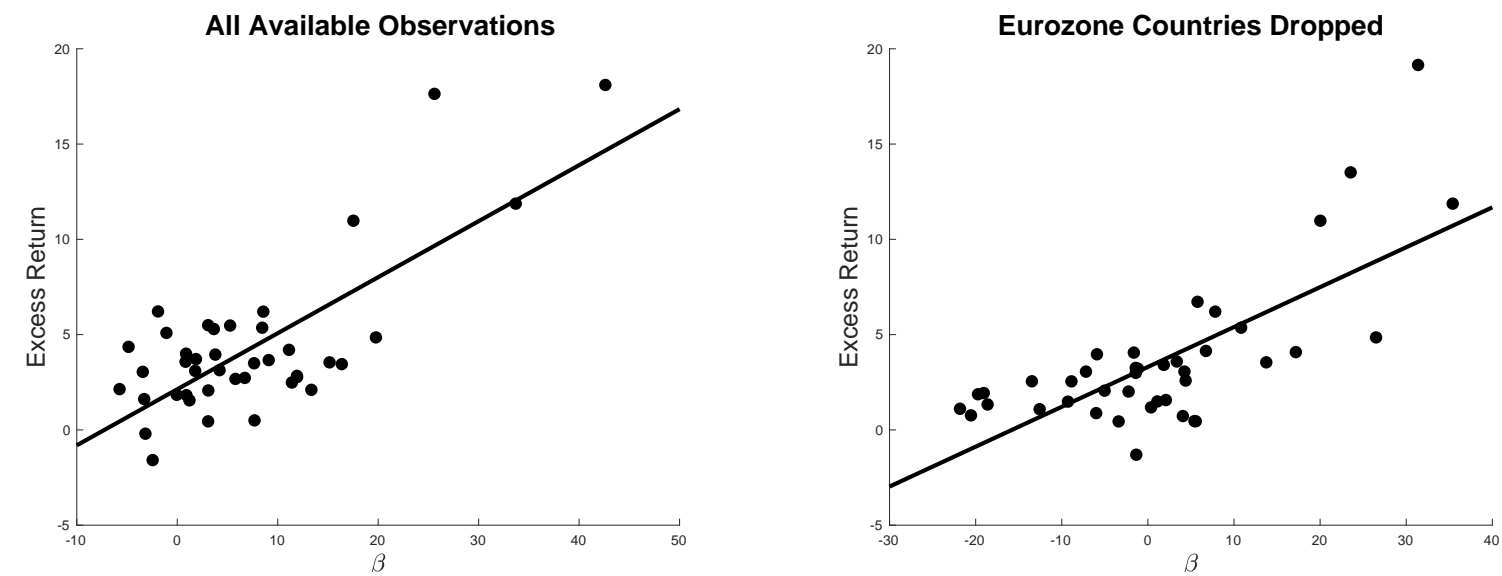

Notes: The raw data are quarterly (1973Q1 to 2014Q2) and, when available, are end-of-quarter and pointsampled. For each country (41 countries plus the euro area), we compute the 'conditional' unemployment rate gap skewness using an 18-quarter window. Individual currency excess returns are in USD, set relative to the U.S. nominal interest rate, and are stated in percent per annum. The figure plots individual country carry-trade-generated average excess returns against their betas.

Our results share similarities with Lustig et al. (2011). In both papers, the global risk factor connects with the concept of global macroeconomic uncertainty. Their relative asset pricing work identifies the high-minus-low currency excess returns between $P_{6}$ and $P_{1}$ portfolios as the global risk factor, which they argue is associated with changes in global equity market volatility.

Developed Countries. Are our results driven entirely by emerging market economies? To address this question, we restrict the sample to developed economies. ${ }^{14}$ As seen in Table 10,

\footnotetext{
${ }^{14}$ We omit Brazil, Chile, Colombia, Czech Republic, Hungary, Indonesia, India, Malaysia, Mexico, Philippines, Romania, South Africa, Thailand, and Turkey.
} 
the factor is significantly priced at the $10 \%$ level, into the six portfolio excess returns formed only by developed countries.

Table 10: Two-Pass Estimation of the Single-Factor Beta-Risk Model on Carry Excess Returns, Developed Countries Only, 1977Q3-2014Q2

\begin{tabular}{l|rrrr}
\hline \hline Factor & $\lambda_{\text {skew }}$ & $\gamma$ & $R^{2}$ & Test-stat \\
\hline$U E^{\text {gap }}$ & $0.891^{*}$ & 4.764 & 0.823 & 1.146 \\
& {$[1.663]$} & {$[1.496]$} & & $(0.950)$ \\
\hline \hline
\end{tabular}

Notes: See notes to Table 1. The developed country sample omits Brazil, Chile, Colombia, Czech Republic, Hungary, Indonesia, India, Malaysia, Mexico, Philippines, Romania, South Africa, Thailand, and Turkey.

Relation to Lustig et al. (2011) factors. Does the $\mathrm{HML}_{\text {skew }}$ of the unemployment gap factor dominate successful risk factors previously found in the currency excess return literature? We address this by comparing our factor with the dollar risk factor (RX) and the carry trade risk factor $\left(\mathrm{HML}_{F X}\right)$ from Lustig et al. (2011). Lustig et al. (2011) show that these two factors can adequately explain carry-trade-generated excess returns. The dollar risk factor is the cross-sectional average of carry-trade-generated excess returns. The carry trade risk factor is the excess return from going long in the high interest rate portfolio and going short in the low interest rate portfolio.

Table 11: Two-Pass Estimation of the Two-Factor Beta-Risk Model on Carry Excess Returns, 1977Q3-2014Q2. RX, $\mathrm{HML}_{F X}$, and $\mathrm{HML}_{\text {skew }}$ of the $\mathrm{UE}^{\text {gap }}$.

\begin{tabular}{l|rrrrr}
\hline \hline Factor & $\lambda_{1}$ & $\lambda_{2}$ & $\gamma$ & $R^{2}$ & Test-stat \\
\hline HML $_{F X}$ & $\mathbf{0 . 6 0 9}$ & 0.032 & $4.544^{*}$ & 0.986 & 0.393 \\
& {$[2.501]$} & {$[0.960]$} & {$[1.773]$} & & $(0.996)$ \\
$R X$ & $\mathbf{0 . 6 0 1}$ & -0.021 & 11.085 & 0.982 & 0.122 \\
& {$[2.647]$} & {$[-0.767]$} & {$[0.947]$} & & $(1.000)$ \\
\hline \hline
\end{tabular}

Notes: We estimate a two-factor model with the $\mathrm{HML}_{\text {skew }}$ of the unemployment rate gap as the maintained first factor (associated with $\lambda_{1}$ ) and each of the alternative factor constructions $\left(\mathrm{HML}_{F X}\right.$ and $R X$ ) as the second factor (associated with $\lambda_{2}$ ) to assess the impression that $\mathrm{HML}_{\text {skew }}$ of the unemployment rate gap is the dominant factor. $\mathrm{HML}_{F X}$ is the carry trade risk factor and $R X$ is the dollar risk factor. These two factors are from Lustig et al. (2011). See notes to Table 1.

Table 11 shows the estimation results from the two-factor model where $\mathrm{HML}_{\text {skew }}$ of the 
unemployment gap is the maintained first factor and the second risk factor is either RX or $H M L_{F X}$. The $\mathrm{HML}_{\text {skew }}$ of the unemployment gap factor remains significantly priced into the excess returns. Neither the dollar factor nor the carry trade factor are significantly priced into the excess returns when the $\mathrm{HML}_{\text {skew }}$ of the unemployment gap is included as a factor.

\section{Two Illustrations}

The empirical work above does not say that countries with high (low) unemployment gap skewness have high (low) interest rates and pay out high (low) currency excess returns. It says investors pay attention to the $\mathrm{HML}_{\text {skew }}$ of the unemployment gap factor, as a global risk factor.

In this section, we give two illustrations of how this global risk factor might be connected to currency returns and to give some interpretation and context for the empirical results. We do not intend these to serve as serious quantitative models, but as illustrative examples of the heterogeneity in the way SDFs across countries load on the global factor.

We begin with the pricing relationships implied by investor Euler equations in a complete markets environment,

$$
\begin{aligned}
r_{i, t} & =\mu_{i, t}+0.5 V_{i, t}, \\
\Delta s_{i, t} & =n_{i, t}-n_{0, t}, \\
R_{i, t+1}^{e} & =0.5\left(V_{0, t}-V_{i, t}\right)+\epsilon_{i, t+1},
\end{aligned}
$$

where $R_{i, t+1}^{e}=\Delta s_{i, t+1}+r_{i, t}-r_{0, t}$ is the excess dollar return, $n_{i, t}$ is country $i^{\prime} s \log$ nominal $\mathrm{SDF}, \mu_{i, t}$ is the conditional mean of country $i^{\prime} s \log$ nominal SDF, and $V_{i, t}$ is the conditional variance of country $i^{\prime} s \log$ nominal SDF. Equation $(11)$ comes from $E_{t}\left(R_{i, t+1}^{e}\right)=$ 
$0.5\left(V_{0, t}-V_{i, t}\right)$ and $\epsilon_{i, t+1}$ is the expectational error. ${ }^{15}$

Systematic variation in the currency excess return $R_{i, t+1}^{e}$ results from systematic variation in $V_{0, t}-V_{i, t}$. Country-level SDFs may load on country-specific factors, but in order for portfolios with higher $\mathrm{HML}_{\text {skew }}$ of unemployment gap betas to have higher returns, the SDFs must also load differentially on the global factor. Thus, heterogeneity across countries in the SDF loading on the global factor is an essential ingredient for understanding patterns in the variation of international currency returns. We give two illustrations of this heterogeneity.

Consumption Growth and Constant Relative Risk Aversion Utility. If investors have constant relative risk averse utility, then the $\log \mathrm{SDF}$ is proportional to the consumption growth rate, and heterogeneity in consumption growth exposure is also heterogeneity in SDF exposure. Our first illustration of heterogeneity in exposure to the $\mathrm{HML}_{\text {skew }}$ of the unemployment gap is where we regress the consumption growth rate of each country on the $\mathrm{HML}_{\text {skew }}$ of the unemployment gap. Figure 4 is a histogram of country-level consumption growth exposure (estimated slope coefficients). The result is substantial heterogeneity in exposure-some countries exhibiting positive and others negative exposure. Many of the more extreme exposure estimates are statistically significantly different from zero. This heterogeneity might have been expected, given the low cross-country correlation of consumption-a long-standing puzzle in international macroeconomics.

\footnotetext{
${ }^{15}$ See Backus et al. (2001).
} 
Figure 4: Consumption Growth Exposure to $\mathrm{HML}_{\text {skew }}$ of the $U E^{\text {gap }}$

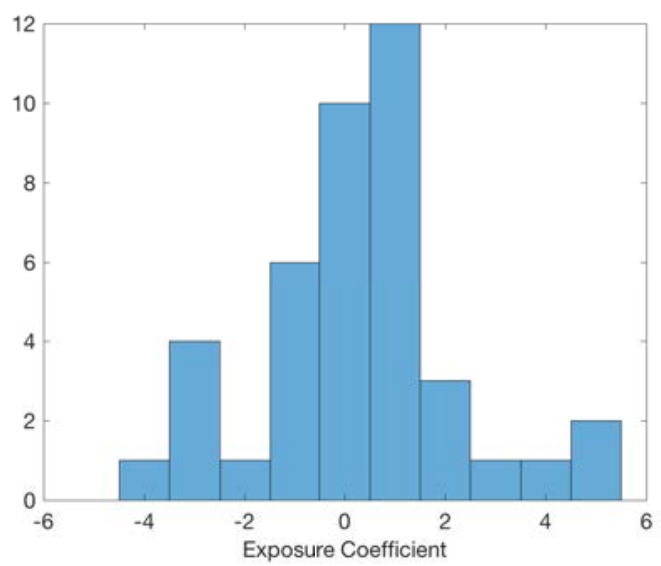

Colacito and Croce (2011) estimate long-run risk across various countries by regressing a country's consumption growth on lagged macro and financial variables. ${ }^{16}$ Is it possible that the lagged $\mathrm{HML}_{\text {skew }}$ unemployment gap is also capturing a long-run risk component in consumption? The Eurozone and Chile are two countries where we have relatively long time-series of quarterly consumption and where their consumption growth rates appear to exhibit some systematic variation. Figure 5 plots actual consumption growth and the fitted values for the Eurozone and Chile, where it appears that the factor is capturing a long-run risk component in consumption growth.

\footnotetext{
${ }^{16}$ Their variables were the lagged price-dividend ratio, consumption-output ratio, default premia, and consumption growth.
} 
Figure 5: Eurozone and Chile: Actual Consumption Growth and Fitted to $\mathrm{HML}_{\text {skew }}$ of the $U E^{\text {gap }}$
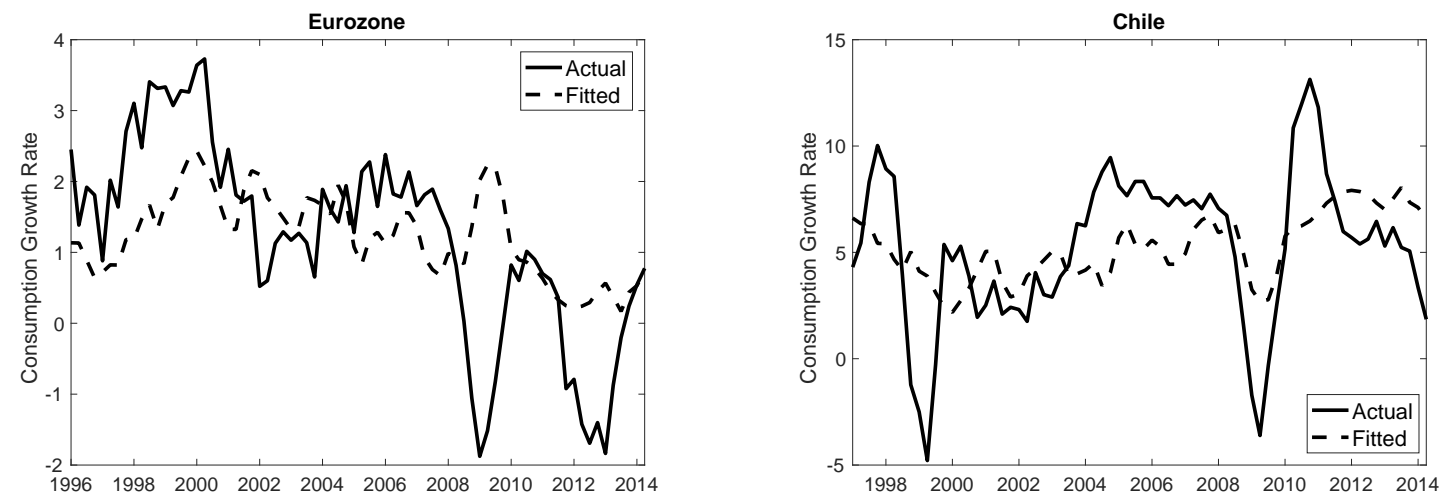

An Affine-Yield Model. As an alternative illustration, we draw on a no-arbitrage model for interest rates and exchange rates. The model is closely related to Backus et al. (2001) and Lustig et al. (2011)'s affine-yield models of the term structure to pricing currency excess returns.

To ease notation, we will call the global risk factor $z_{g, t}=\mathrm{HML}_{\text {skew }}$ of the unemployment gap. Let $z_{i, t}$ be a country-specific risk factor. Investors pay attention to both the global and country-specific risk factors through their impact on the log nominal SDF, $n_{i, t+1}$, according to

$$
n_{i, t+1}=-\theta_{i}\left(z_{i, t}+z_{g, t}\right)-u_{i, t+1} \sqrt{\omega_{i} z_{i, t}}-u_{g t+1} \sqrt{\kappa_{i} z_{i, t}+\delta_{i} z_{g, t}},
$$

where the dynamics of the global and country-specific risk factors are first-order autore- 
gressive processes with stochastic volatility,

$$
\begin{aligned}
z_{g, t+1} & =\left(1-\phi_{g}\right) \chi_{g}+\phi_{g} z_{g, t}+u_{g, t+1} \sqrt{z_{g, t}} \\
z_{i, t+1} & =\left(1-\phi_{i}\right) \chi_{i}+\phi_{i} z_{i, t}+u_{i, t+1} \sqrt{z_{i, t}} \\
u_{g, t} & =\sigma_{g} v_{g, t} \\
u_{i, t} & =\sigma_{i}\left(\rho_{i} v_{g, t}+v_{i, t} \sqrt{\left(1-\rho_{i}^{2}\right)}\right)
\end{aligned}
$$

and $v_{g, t}$ and $v_{i, t}$ are independent standard normal variates. Since the global factor must be built from an aggregation of country factors, we allow the country-specific innovation to be correlated with the global innovation $E\left(u_{i, t} u_{g, t}\right)=\rho_{i}$.

The conditional mean $\left(\mu_{i, t}\right)$ and conditional variance $\left(V_{i, t}\right)$ of the log nominal SDF are

$$
\begin{aligned}
& \mu_{i, t}=-\theta_{i}\left(z_{i, t}+z_{g, t}\right) \\
& V_{i, t}=\sigma_{g}^{2} \delta_{i} z_{g, t}+\left(\sigma_{g}^{2} \kappa_{i}+\sigma_{i}^{2} \omega_{i}\right) z_{i, t}+2 \sigma_{g} \sigma_{i} \rho_{i} \sqrt{\omega_{i} z_{i, t}} \sqrt{\kappa_{i} z_{i, t}+\delta_{i} z_{g, t}} .
\end{aligned}
$$

Heterogeneity in the risk-factor loadings on the log SDFs is not necessary to generate time-varying currency excess returns (i.e., differences in conditional variances), which can be achieved through differences in the realizations of country-specific risk $z_{i, t}$. What is key, however, is that the $\log$ SDFs load on the global factor $z_{g t}$. If they do not, excess currency returns may be non-zero, but they will not be priced by the global risk factor.

We proceed by estimating the model by simulated method of moments, then simulating the model and assessing the properties of the implied currency returns as described in equations (9)-(11). ${ }^{17}$

We begin by estimating the process for the global risk factor $\left(\mathrm{HML}_{\text {skew }}\right.$ of the unemployment rate gap) $z_{g, t}$ separately. Parameters in equation (13) are estimated by simulated

\footnotetext{
${ }^{17}$ See Lee and Ingram (1991). 100,000 is the length of the simulated time series.
} 
method of moments and are shown in Table 12 .

Table 12: SMM Estimates of the Global Risk Factor Process

\begin{tabular}{lrrr}
\hline \hline & $\chi_{g}$ & $\phi_{g}$ & $\sigma_{g}$ \\
\hline Estimate & 1.523 & 0.872 & 0.395 \\
t-ratio & 20.715 & 13.333 & 15.453 \\
\hline \hline
\end{tabular}

Notes: Simulated method of moments estimates of the global risk factor $\left(\mathrm{HML}_{\text {skew }}\right.$ of the unemployment rate gap) process, described in equation (13). The moments used in the estimation include $E\left(z_{g, t}\right), E\left(z_{g, t}^{2}\right)$, $E\left(z_{g, t} z_{g, t-1}\right), E\left(z_{g, t} z_{g, t-2}\right), E\left(z_{g, t}^{2} z_{g, t-1}^{2}\right)$, and $E\left(z_{g, t} z_{g, t-2}^{2}\right)$.

Next, we estimate the parameters of each country's nominal SDF. Recall that we do not have a balanced panel, as the time-span coverage varies by availability. Our data sample consists of 41 countries that can be bilaterally paired with the United States (country '0'). Of these 41 countries, 38 have sufficiently long time-series data that we use in the estimation. Estimation is done bilaterally. The 14 moments we use in the estimation are $E\left(h_{i, t}\right)$, where

$$
\begin{aligned}
h_{i, t}^{\prime}= & \left(\Delta s_{i, t}, \Delta s_{i, t}^{2}, \Delta s_{i, t} \Delta s_{i, t-1}, \Delta s_{i, t} \Delta s_{i, t-4}, R_{i, t}^{e},\left(R_{i, t}^{e}\right)^{2}, \ldots\right. \\
& \left.R_{i, t}^{e} R_{i, t-1}^{e}, R_{i, t}^{e} R_{i, t-4}^{e}, r_{i, t}, r_{i, t}^{2}, r_{i, t} r_{i, t-1}, r_{0, t}, r_{0, t}^{2}, r_{0, t} r_{0, t-1}\right)
\end{aligned}
$$

We estimate three versions of the model. In one version, the SDFs do not load on the global factor. In the other restricted model, the SDFs load only on the global factor but not on the country-specific factors. In the third version, the SDFs load on both the country-specific and global factors.

We are primarily interested in seeing if the heterogeneity in the estimated parameters is sufficient to generate carry-trade-generated currency returns as found in the data. There are a large number of estimation results, the details of which are not essential. To provide a sense of the heterogeneity uncovered in estimation, Figure 6 presents histograms of the estimated values of the loadings on the global factor, $\theta_{i}$ and $\delta_{i}$, from the unconstrained model. 
Figure 6: Country Log SDF Exposure to $\mathrm{HML}_{\text {skew }}$ of the $U E^{\text {gap }}$ from the Unconstrained Model
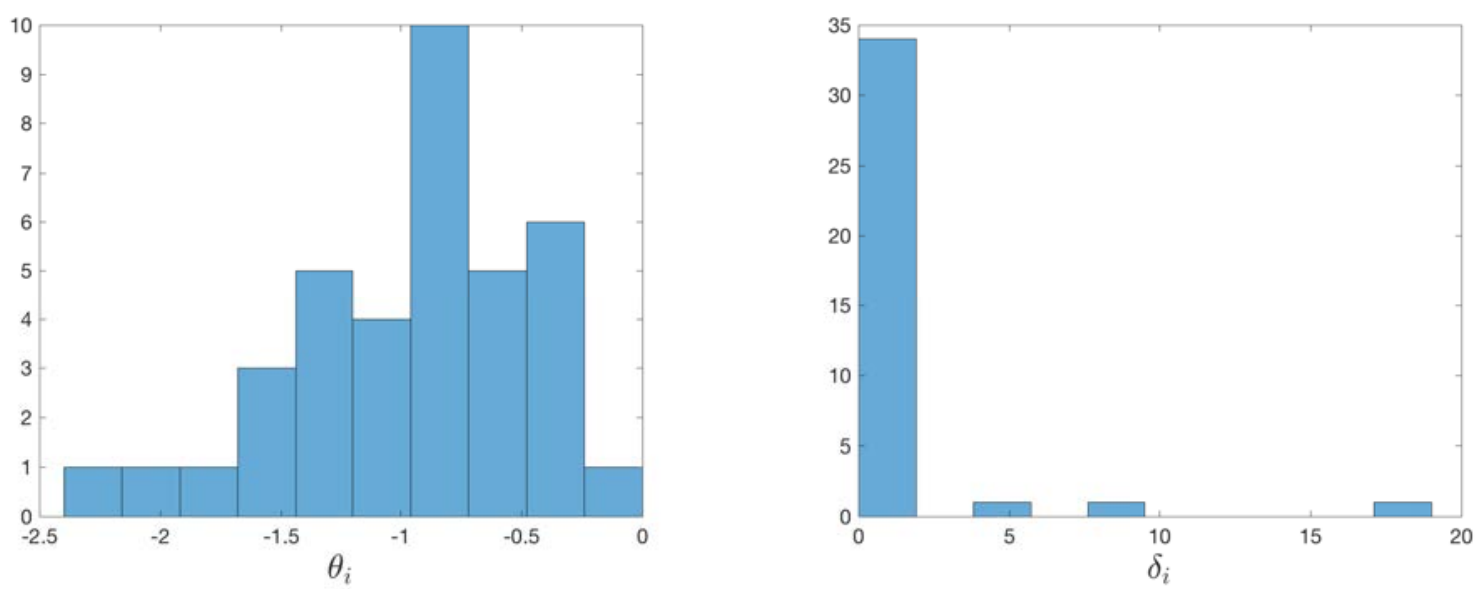

We simulate the three versions of the estimated model. In each of the 2,000 simulations, we generate 87 observations on exchange rate returns and interest rates across the 38 countries and the United States. In the data, we had, on average, 87 time-series observations. For each replication, we sort currencies into six interest rate ranked portfolios, compute their mean excess (over the U.S.) returns and Sharpe ratios, and estimate the single-factor beta-risk model. Table 13 reports the median values over the 2,000 simulations. 
Table 13: Excess Returns and Two-Pass Estimation of the Single-Factor Beta-Risk Model on Simulated Carry Excess Returns

\begin{tabular}{|c|c|c|c|c|c|c|}
\hline \multicolumn{7}{|c|}{ A. Simulated Excess Return Summary Statistics } \\
\hline & $P_{1}$ & $P_{2}$ & $P_{3}$ & $P_{4}$ & $P_{5}$ & $P_{6}$ \\
\hline \multicolumn{7}{|l|}{ No Global Loadings } \\
\hline Average returns by portfolios & -11.526 & -9.096 & -5.517 & -1.052 & 3.672 & 31.128 \\
\hline Sharpe & -6.226 & -4.259 & -2.346 & -0.381 & 1.075 & 2.672 \\
\hline \multicolumn{7}{|l|}{ No Country-Specific Loadings } \\
\hline Average returns by portfolios & -2.723 & 1.112 & 5.838 & 8.980 & 12.135 & 18.163 \\
\hline Sharpe & -1.517 & 0.655 & 1.432 & 1.522 & 1.535 & 1.593 \\
\hline \multicolumn{7}{|l|}{ Unconstrained } \\
\hline Average returns by portfolios & -2.611 & 2.212 & 5.120 & 9.140 & 12.424 & 18.298 \\
\hline Sharpe & -1.181 & 1.201 & 1.826 & 2.114 & 2.149 & 2.209 \\
\hline \multicolumn{7}{|c|}{ B. Single-Factor Model Estimated on Simulated Observations } \\
\hline & $\lambda$ & $\gamma$ & $R^{2}$ & Test-stat & & \\
\hline \multirow[t]{2}{*}{ No Global Loadings } & -2.155 & -4.531 & 0.838 & 9.353 & & \\
\hline & {$[-0.208]$} & {$[-1.095]$} & & $(0.096)$ & & \\
\hline \multirow[t]{2}{*}{ No Country-Specific Loadings } & 1.867 & 0.866 & 0.999 & 14.293 & & \\
\hline & {$[7.314]$} & {$[2.428]$} & & $(0.014)$ & & \\
\hline \multirow[t]{2}{*}{ Unconstrained } & 2.803 & 2.976 & 0.897 & 14.584 & & \\
\hline & [8.629] & {$[4.637]$} & & $(0.012)$ & & \\
\hline
\end{tabular}

Notes: We simulate the model of equations (9)-(11) 2,000 times. For each simulation, we generate 87 observations (to match the 87 time-series observations available, on average, in the data) on exchange rate returns and interest rates for 38 countries and the United States. For each simulation, currencies are sorted into six interest rate ranked portfolios. We then compute their mean excess returns (over the U.S.), their Sharpe ratios. Panel A shows the median values across the 2,000 simulations. Panel B shows the median of the second stage estimates of the beta-risk model. $\lambda$ is the slope on the global factor beta and $\gamma$ is the constant term. t-ratios are in brackets and p-values are in parentheses.

In each of the models, the simulated carry-trade-generated average excess returns are increasing as one moves from $P_{1}$ to $P_{6}$ (panel A). Even when country SDFs load only on country-specific factors, the carry trade is profitable, the average implied return on $P_{6}$ being 31 percent. The estimated heterogeneity in the two versions where country SDFs load on $\mathrm{HML}_{\text {skew }}$ of the unemployment gap imply average excess returns that are more realistic, but still somewhat larger than seen in the data.

Panel B shows median estimates of the implied beta-risk model. Here, it is verified that the global risk factor is unpriced if the SDFs do not load on that factor. The median 
t-ratio on $\lambda$ is far from 2 , even though the median $R^{2}$ value is quite high. The median point estimate of $\lambda$ is negative.

The global-risk factor is priced in the other two versions of the model. The median $R^{2}$ is similar to that obtained from the data, the median t-ratio is significant, and the median point estimate of $\lambda$ is positive.

The point of the exercise in this section is not to replicate exactly the moments of the data but to illustrate the link between the global factor and carry-trade-generated excess returns. The unconstrained model captures three broad features of the data. Average excess returns are generally increasing in the carry-trade portfolios $P_{1}$ through $P_{6}$, the forward premium anomaly is more pronounced when portfolio interest rates are more similar to U.S. rates, and investor SDFs must load on the global factor. Probably, their SDFs load also on country-specific factors as well.

\section{Conclusion}

It has long been understood that systematic currency excess returns (deviations from uncovered interest parity) are available to investors. Less well understood is what risks are being compensated for by the excess returns. In a financially integrated world, excess returns should be driven by common factors. We find that a global risk factor, constructed as the high-minus-low conditional skewness of the unemployment rate gap, is priced into carry-trade-generated excess returns. Carry-trade-generated currency excess returns compensate for global macroeconomic risks.

There are three notable features of this risk factor. First, it is a macroeconomic fundamental. As Lustig and Verdelhan (2011) point out, since the statistical link between asset returns and macroeconomic factors is always weaker than the link between asset returns and return-based factors, the high explanatory power provided by this factor and its 
significance is noteworthy. Second, the factor is global in nature. It is constructed from averages of countries in the top and bottom quartiles of the unemployment rate gap skewness. Since the portfolios of carry-trade-generated excess returns are available to global investors, only global risk factors should be priced. Third, the factor measures something different from standard measures of global uncertainty. Embracing notions of both country-level uncertainty and global uncertainty, the high-minus-low global macro risk factor captures asymmetries in the distribution of the global state that reflect the divergence, disparity, and inequality of fortunes across countries. 


\section{References}

[1] Alvarez, Fernando, Andrew Atkeson, and Patrick J. Kehoe, 2009. "Time-Varying Risk, Interest Rates and Exchange Rates in General Equilibrium," Review of Economic Studies, 76, 851-878.

[2] Ang, Andrew and Joseph S. Chen. 2010. "Yield Curve Predictors of Foreign Exchange Returns," mimeo, Columbia University.

[3] Backus, David K., Silverio Foresi, and Chris I. Telmer. 2001. "Affine Term Structure Models and the Forward Premium Anomaly," Journal of Finance, 56, 279-304.

[4] Baker, Scott R., Nicholas Bloom, and Steven J. Davis. 2016. "Measuring Economic Policy Uncertainty," www.policyuncertainty.com.

[5] Bansal, Ravi and Ivan Shaliastovich. 2012. "A Long-Run Risks Explanation of Predictability Puzzles in Bond and Currency Markets," Review of Financial Studies, 26, 1-33.

[6] Bilson, John F.O. 1981. "The 'Speculative Efficiency' Hypothesis," Journal of Business, 54, 435-51.

[7] Brunnermeier, Markus K., Stefan Nagel, and Lasse Pedersen. 2009. "Carry Trades and Currency Crashes," NBER Macroeconomics Annual, 2008, 313-347.

[8] Burnside, C. 2011a. "The Cross Section of Foreign Currency Risk Premia and Consumption Growth Risk: Comment," American Economic Review, 101, 3456-3476.

[9] Burnside, C. 2011b. "The Cross Section of Foreign Currency Risk Premia and Consumption Growth Risk: Appendix," Online Appendix, https://www.aeaweb.org/articles.php?doi=10.1257/aer.101.7.3456. 
[10] Burnside, Craig, Martin Eichenbaum, Isaac Kleshchelski, and Sergio Rebelo. 2011. "Do Peso Problems Explain the Returns to the Carry Trade?" Review of Financial Studies, 24, 853-891.

[11] Chinn, Menzie and Guy Merideth, 2004. "Monetary Policy and Long Horizon Uncovered Interest Parity," IMF Staff Papers, 51, 409-430.

[12] Chinn, Menzie and Yi Zhang, 2015. "Uncovered Interest Parity and Monetary Policy Near and Far from the Zero Lower Bound," mimeo University of Wisconsin.

[13] Christiansen, Charlott, Angelo Ranaldo, and Paul Söderlind, 2011. "The Time-Varying Systematic Risk of Carry Trade Strategies," Journal of Financial and Quantitative Analysis, 46, 1107-25.

[14] Clarida, Richard, Josh Davis, and Niels Pederson. 2009. "Currency Carry Trade Regimes: Beyond the Fama Regression," Journal of International Money and Finance, $28,1365-1389$.

[15] Cochrane, John H. 2005. Asset Pricing. Princeton and Oxford: Princeton University Press.

[16] Colacito, Riccardo and Marian M. Croce. 2011. "Risks for the Long Run and the Real Exchange Rate," Journal of Political Economy, 119, 153-182.

[17] Colacito, R., M.M. Croce, F. Gavazzoni, and R. Ready, 2015. "Currency Risk Factors in a Recursive Multi-Country Economy," mimeo, University of North Carolina, Chapel Hill.

[18] Cumby, Robert E. 1988. "Is it Risk? Explaining Deviations from Uncovered Interest Parity," Journal of Monetary Economics, 22, 279-99. 
[19] Daniel, Kent, Robert J. Hodrick, and Zhongjin Lu, 2014. "The Carry Trade: Risks and Drawdowns," NBER Working Paper 20433.

[20] Della Corte, P., L. Sarno, M. Schmeling, and C. Wagner (2015), "Exchange Rates adn Sovereign Risk," mimeo, Imperial College Business School.

[21] Della Corte, P., S. Riddiough, and L. Sarno (2016). "Currency Premia and Global Imbalances," Review of Financial Studies, forthcoming.

[22] Devereux, Michael and Charles Engel, 2003. "Monetary Policy in the Open Economy Revisited: Price Setting and Exchange-Rate Flexibility," Review of Economic Studies, 70, 765-783.

[23] Du, Wenxin, Alexander Tepper, and Adrien Verdelhan, 2016. "Deviations from Covered Interest Parity," mimeo, Board of Governors of the Federal Reserve Board.

[24] Engel, Charles. 1996. "The Forward Discount Anomaly and the Risk Premium: A Survey of Recent Evidence," Journal of Empirical Finance, 3, 123-192.

[25] Engel, Charles. 2015. "Exchange Rates and Interest Parity," Handbook of International Economics, Volume 4.

[26] Engel, Charles. 2016. "Exchange Rates, Interest Rates, and the Risk Premium," American Economic Review, 106(2): 436-474.

[27] Epstein Lawrence and Stanley Zin. 1989. "Substitution, Risk Aversion and the Temporal Behavior of Consumption and Asset Returns: A Theoretical Framework," Econometrica, 57, 937-969.

[28] Fama, Eugene F. 1984. "Forward and Spot Exchange Rates," Journal of Monetary Economics, 14, 319-338. 
[29] Fama, Eugene F. and Kenneth R. French, 1996. "Multifactor Explanations of AssetPricing Anomalies," Journal of Finance 50, 131-155.

[30] Frankel, Jeffrey A. and Charles Engel. 1984. "Do Asset-Demand Functions Optimize over the Mean and Variance of Real Returns? A Six-Currency Test," Journal of International Economics, 17, 309-323.

[31] Hansen, Lars P. and Robert J. Hodrick. 1980. "Forward Exchange Rates as Optimal Predictors of Future Spot Rates: An Econometric Analysis," Journal of Political Economy, 88(5), 829-853.

[32] Hassan, Tarek A. 2013. "Country Size, Currency Unions, and International Asset Returns," Journal of Finance, 68, 2269-2308.

[33] Hassan, Tarek A. and Rui C. Mano. 2014. "Forward and Spot Exchange Rates in a Multi-currency World," NBER Working paper 20294.

[34] Hodrick, Robert J. 1987. The Empirical Evidence on the Efficiency of Forward and Futures Foreign Exchange Markets, Chur: Harwood.

[35] Hodrick, Robert J. and Edward C. Prescott. 1997. "Postwar U.S. Business Cycles: An Empirical Investigation," Journal of Money, Credit and Banking, 29, 1-16.

[36] Jordà, Òscar and Alan M. Taylor. 2012. "The Carry Trade and Fundamentals: Nothing to Fear but FEER itself," Journal of International Economics, 88, pp. 74-90.

[37] Jurek, Jakub W. 2014. "Crash-Neutral Currency Carry Trades," Journal of Financial Economics, 113, pp. 325-347.

[38] Itskhoki, Oleg and Dmitry Mukhin. 2016. "Exchange Rate Disconnect in General Eqilibrium," mimeo Princeton University. 
[39] Kollmann, Robert, 2002. "Monetary policy rules in the open economy: effects on welfare and business cycles," Journal of Monetary Economics, 49: 989-1015.

[40] Lee, Bong-Soo and Beth Fisher Ingram. 1991. "Simulation Estimation of Time-Series Models," Journal of Econometrics 47, 197-205.

[41] Lettau, Martin, Matteo Maggiori, and Michael Weber. 2014. "Conditional Risk Premia in Currency Markets and Other Asset Classes," Journal of Financial Economics, 114, pp. $197-225$.

[42] Lewis, Karen K. 1995. "Puzzles in International Financial Markets," in G. Grossman and K. Rogoff, eds. Handbook of International Economics (North Holland: Amsterdam).

[43] Lustig, Hanno and Adrien Verdelhan. 2007. "The Cross Section of Foreign Currency Risk Premia and Consumption Growth Risk," American Economic Review, 97, 89-117.

[44] Lustig, Hanno and Adrien Verdelhan. 2012. "Exchange Rates in a Stochastic Discount Factor Framework," in Handbook of Exchange Rates, Jessica James, Ian W. Marsh, and Lucio Sarno, eds., Wiley.

[45] Lustig, Hanno, Nikolai Roussanov, and Adrien Verdelhan. 2011. "Common Risk Factors in Currency Markets," Review of Financial Studies, 24, 3731-3777.

[46] Mark, Nelson C. 1985. "On Time Varying Risk Premia in the Foreign Exchange Market: An Econometric Analysis," Journal of Monetary Economics, 16, 3-18.

[47] Mark, Nelson C. 1988. "Time-Varying Betas and Risk Premia in the Pricing of Forward Foreign Exchange Contracts," Journal of Financial Economics, 22, 335-54.

[48] Menkhoff, Lukas, Lucio Sarno, Maik Schmeling, and Andreas Schrimpf. 2012. "Carry Trades and Global Foreign Exchange Volatility," Journal of Finance, 67, 681-718. 
[49] Menkhoff, Lukas, Lucio Sarno, Maik Schmeling, and Andreas Schrimpf. 2013. "Currency Risk Premia and Macro Fundamentals," mimeo, Cass Business School, City University London.

[50] Newey, Whithey K. and Kenneth D. West. 1987. "A Simple, Positive Semidefinite, Heteroskedasticity and Autocorrelation Consistent Covariance Matrix," Econometrica, $55,703-708$.

[51] Orphanides, Athanasios and John C. Williams. "The Decline of Activist Stabilization Policy: Natural Rate Misperceptions, Learning, and Expectations," Journal of Economic Dynamics and Control, Vol. 29, No. 11 (2005): 1927-1950.

[52] Orphanides, Athanasios and John C. Williams. "Monetary Policy with Imperfect Knowledge," Journal of the European Economic Association, Vol. 4, No. 2-3 (2006): $366-375$.

[53] Orphanides, Athanasios and John C. Williams. "Robust Monetary Policy with Imperfect Knowledge," Journal of Monetary Economics, Vol. 54, No. 5 (2007): 1406-1435.

[54] Pinnington, James and Maral Shamloo. 2016. "Limits to Arbitrage and Deviations from Covered Interest Parity," mimeo Bank of Canada.

[55] Ready, Robert, Nikolai Roussanov, and Colin Ward. 2015. "After the Tide: Commodity Currencies and Global Trade," mimeo, University of Pennsylvania.

[56] Verdelhan, Adrien. 2010. "A Habit-Based Explanation of the Exchange Rate Risk Premium," The Journal of Finance, 65, 123-146. 


\section{Appendix A}

\section{Additional Notes on the Data}

All interest rates are for 3-months maturity.

Australia: 73.1-86.1, 3 month T-bill rate. 86.2-14.2, 3-month interbank rate.

Austria: 91.2-98.4, EIBOR (Emirates Interbank Offer Rate, Datastream).

Belgium: 73.1-89.4, 3-month eurocurrency (Harris). 90.1-98.4, EIBOR.

Brazil: 04.1-14.2, Imputed from spot and forward rates (Datastream).

Canada: 73.1-96.1, 3-month eurocurrency. 96.2-14.2, 3-month T-bill rate.

Chile: 04.1-13.2, Imputed from spot and forward rates.

Colombia: 04.1-13.2, Imputed from spot and forward rates.

Czech Republic: 92.2-14.2, Interbank rate.

Denmark: 84.4-88.1, imputed from spot and forward rates. 88.2-14.2, Interbank rate.

Euro zone: 99.1-14.2, Interbank rate, Germany.

Finland: 87.1-98.4, EIBOR.

France: 73.1-96.1, 3-month eurocurrency. 96.2-98.4, EIBOR.

Germany: 73.1-96.1, 3-month eurocurrency. 96.2-98.4, EIBOR.

Greece: 94.2-98.4. Interbank.

Hungary: 95.3-14.2: Interbank.

Iceland: 95.3-00.1, Interbank mid-rate. 00.2-14.2, Reykjavik interbank offer rate.

India: 97.4-98.3, Imputed from spot and forward rates. 98.4-14.2 Interbank.

Indonesia: 96.1-14.2, Interbank rate.

Ireland: 84.1-98.4. Interbank.

Israel: 94.4-99.3, T-bill. 99.4-14.2, Interbank.

Italy: 73.1-96.1, 3-month eurocurrency. 96.2-98.4, EIBOR.

Japan: 73.1-96.1, 3-month eurocurrency. 96.2-14.2, Interbank. 
Malaysia: 93.3-14.2, Interbank.

Mexico: 78.1-14.2, T-bill (FRED).

Netherlands: 73.1-96.1, 3-month eurocurrency. 96.2-98.4, EIBOR.

New Zealand: 74.1-13.4, Interbank (FRED).

Norway: 86.1-14.2. Interbank.

Philippines: 87.1-14.2 T-bill.

Poland: 94.4-14.2 Interbank.

Portugal: 96.4-98.4, Imputed from spot and forward.

Romania: 95.3-14.2. Interbank.

Singapore: 84.4-87.2, Imputed from spot and forward rates. 87.3-13.4, Interbank.

South Africa: 73.1-14.3. T-bill.

South Korea: 92.1-14.2. Interbank.

Spain: 88.3-98.4, Interbank.

Sweden: 84.4-86.4, Imputed from spot and forward rates. 87.1-14.3, Interbank.

Switzerland: 73.1-96.1, 3-month eurocurrency. 96.2-14.2, Interbank.

Taiwan: 82.2-14.2, Money market rates.

Thailand: 95.1-96.3, imputed from spot and forward rates. 96.5-14.2, Interbank.

Turkey: 96.4-06.4, imputed from spot and forward rates. 07.1-14.2, Interbank.

United Kingdom: 73.1-96.1, 3-month eurocurrency. 96.2-98.4, U.K. Interbank.

\section{Appendix B}

\section{Two-Pass Regression Procedure and GMM Standard Errors}

We have $k$ factors, $T$ time-series observations and $n$ excess returns (assets). Vectors are underlined. Matrices are bolded. Scalars have no special designation. The objective is to 
estimate the $k$-factor 'beta-risk' model

$$
E\left(r_{i, t}^{e}\right)=\underline{\beta}_{i}^{\prime} \underline{\lambda}+\alpha_{i}
$$

where $\beta_{i}$ is a $k$-dimensional vector of the factor betas for excess return $i$ and $\underline{\lambda}$ is the $k$-dimensional vector of factor risk premia. The expectation is taken over $t$. The beta-risk model's answer to the question as to why average returns vary across assets is that returns with high betas (covariance with a factor) pay a high-risk premium $(\underline{\lambda})$. The cross-sectional test can be implemented with a two-pass procedure. Let $\underline{f}_{t}$ be the $k$-dimensional vector of the macro factors. In the first pass for each excess return $i=1, \ldots, n$, estimate the factor betas in the time-series regression,

$$
r_{i, t}^{e}=a_{i}+\underbrace{\left(\beta_{1, i}, \ldots, \beta_{k, i}\right)}_{\underline{\beta}_{i}^{\prime}}\left(\begin{array}{c}
f_{1, t} \\
\vdots \\
f_{k, t}
\end{array}\right)+\epsilon_{i, t}=\underline{\tilde{\beta}}_{i}^{\prime} \underline{F}_{t}+\epsilon_{i, t}
$$

where

$$
\underline{F}_{t}=\left(\begin{array}{c}
1 \\
\underline{f}_{t}
\end{array}\right), \underline{f}_{t}=\left(\begin{array}{c}
f_{1, t} \\
\vdots \\
f_{k, t}
\end{array}\right), \underset{(k+1) \times 1}{\tilde{\beta}_{i}}=\left(\begin{array}{c}
a_{i} \\
\underline{\beta}_{i}
\end{array}\right), \underset{(k \times 1)}{\underline{\beta}_{i}}=\left(\begin{array}{c}
\beta_{1, i} \\
\vdots \\
\beta_{k, i}
\end{array}\right) .
$$

In the second pass, we can run the cross-sectional regression of average returns $\bar{r}_{i}^{e}=$ $(1 / T) \sum_{t=1}^{T} r_{i, t}^{e}$, using the betas as data, to estimate the factor risk premia, $\underline{\lambda}$. If the excess return's covariance with the factor is systematic and undiversifiable, that covariance risk should be 'priced' into the return. The factor risk premium should not be zero. The 
second-pass regression run with a constant is

$$
\bar{r}_{i}^{e}=\gamma+\underbrace{\left(\lambda_{1}, \ldots, \lambda_{k}\right)}_{\underline{\lambda}}\left(\begin{array}{c}
\beta_{1, i} \\
\vdots \\
\beta_{k, i}
\end{array}\right)+\alpha_{i}=\gamma+\underline{\lambda}^{\prime} \underline{\beta}_{i}+\alpha_{i} .
$$

The $\alpha_{i}$ are the pricing errors. When the cross-sectional regression is run without a constant, set $\gamma=0$.

$$
\underline{\underline{r}}_{i}^{e}=\gamma+\underline{\beta}_{i}^{\prime} \underline{\lambda}+\alpha_{i}
$$

OLS standard errors give asymptotically incorrect inference because the $\beta s$ are not data but are generated regressors. Cochrane (2005) describes a procedure to obtain GMM standard errors that delivers an asymptotically valid inference that is robust to the generated regressors problem and robust to heteroskedasticity and autocorrelation in the errors. Cochrane's strategy is to use the standard errors from a GMM estimation problem that exactly reproduces the two-stage regression point estimates. We will need the following 
notation:

$$
\begin{aligned}
& \underset{(k \times k)}{\Sigma_{f}}=E\left(\underline{f}_{t}-\underline{\mu}_{f}\right)\left(\underline{f}_{t}-\underline{\mu}_{f}\right)^{\prime} \\
& \underline{\epsilon}_{t}=\left(\epsilon_{1, t}, \epsilon_{2, t}, \ldots, \epsilon_{n, t}\right)^{\prime} \\
& \sum_{n \times n}=E\left(\underline{\epsilon}_{t} \underline{\epsilon}_{t}^{\prime}\right) \\
& \underset{n \times k}{\mathbf{B}}=\left(\begin{array}{c}
\underline{\beta}_{1}^{\prime} \\
\vdots \\
\underline{\beta}_{n}^{\prime}
\end{array}\right)=\left(\begin{array}{ccc}
\beta_{1,1} & \cdots & \beta_{k, 1} \\
\vdots & & \vdots \\
\beta_{1, n} & \cdots & \beta_{k, n}
\end{array}\right) \\
& \underset{k \times n}{\mathbf{A}}=\underset{k \times k}{\left(\mathbf{B}^{\prime} \mathbf{B}\right)^{-1}} \underset{k \times n}{\mathbf{B}^{\prime}} \\
& \underset{n \times n}{\mathbf{M}_{\beta}}=\mathbf{I}_{n}-\underset{n \times k}{\mathbf{B}}\left(\underset{k \times k}{\left.\mathbf{B}^{\prime} \mathbf{B}\right)^{-1}} \underset{k \times n}{\mathbf{B}^{\prime}}\right. \\
& \underset{n \times(k+1)}{\mathbf{X}}=\left(\underline{\iota}_{n} \mathbf{B}^{\prime}\right) \text {, where } \underline{\iota}_{n}=\left(\begin{array}{c}
1 \\
\vdots \\
1
\end{array}\right) \leftarrow n^{\prime} \text { th row } \\
& \underset{(k+1) \times n}{\mathbf{C}}=\underset{(k+1) \times(k+1)}{\left(\mathbf{X}^{\prime} \mathbf{X}\right)} \quad{\underset{(k+1) \times n}{-1}}_{\mathbf{X}^{\prime}} \\
& \underset{n \times n}{\mathbf{M}_{X}}=\mathbf{I}_{n}-\underset{n \times(k+1)}{\mathbf{X}} \underset{(k+1) \times(k+1)}{\left(\mathbf{X}^{\prime} \mathbf{X}\right)^{-1}} \underset{(k+1) \times n}{\mathbf{X}^{\prime}} \\
& \underset{(k+1) \times(k+1)}{\tilde{\mathbf{\Sigma}}_{f}}=\left(\begin{array}{cc}
0 & \underline{0} \\
\text { scalar } & 1 \times k \\
\underline{0} & \boldsymbol{\Sigma}_{f} \\
k \times k
\end{array}\right)
\end{aligned}
$$

Estimation without the constant. When estimating without the constant in the second- 
pass regression, the parameter vector is

$$
[k(n+1)+k] \times 1=\left(\begin{array}{c}
\tilde{\beta}_{1} \\
\underline{\tilde{A}}_{1} \\
\vdots \\
\tilde{\beta}_{n} \\
\underline{\lambda}
\end{array}\right)=\left(\begin{array}{c}
a_{1} \\
\underline{\beta}_{1} \\
\vdots \\
a_{n} \\
\underline{\beta}_{n} \\
\underline{\lambda}
\end{array}\right)
$$

Let the second moment matrix of the factors be

$$
\underset{(k+1) \times(k+1)}{\mathbf{M}_{F}}=\frac{1}{T} \sum_{t=1}^{T} \underline{F}_{t} \underline{F}_{t}^{\prime} .
$$

The moment conditions are built off of the error vector,

$$
\underline{u}_{n}(\theta)=\left(\begin{array}{c}
\underline{F}_{t}\left(r_{1, t}^{e}-\underline{F}_{t}^{\prime} \underline{\tilde{\beta}}_{1}\right) \\
\vdots \\
\underline{F}_{t}\left(r_{n, t}^{e}-\underline{F}_{t}^{\prime} \underline{\tilde{\beta}}_{n}\right) \\
r_{1, t}^{e}-\underline{\beta}_{1}^{\prime} \underline{\lambda} \\
\vdots \\
r_{n, t}^{e}-\underline{\beta}_{n}^{\prime} \underline{\lambda}
\end{array}\right)=\left(\begin{array}{c}
\underline{F}_{t}\left(r_{1, t}^{e}-\underline{F}_{t}^{\prime} \underline{\underline{\beta}}_{1}\right) \\
\vdots \\
\underline{F}_{t}\left(r_{n, t}^{e}-\underline{F}_{t}^{\prime} \underline{\tilde{\beta}}_{n}\right) \\
\underline{R}_{t}^{e}-\mathbf{B} \underline{\lambda}
\end{array}\right) \leftarrow \operatorname{row} n(k+1)
$$

where

$$
\underline{r}_{t}^{e}=\left(\begin{array}{c}
r_{1, t}^{e} \\
\vdots \\
r_{n, t}^{e}
\end{array}\right)
$$


Let

$$
\begin{aligned}
& \underline{g}_{T}(\underline{\theta})=\frac{1}{T} \sum_{t=1}^{T} \underline{u}_{t}(\theta) \\
& \underset{[n(k+1)] \times[n(k+1)+k]}{\mathbf{d}_{T}}=\frac{\partial \mathbf{g}_{T}(\underline{\theta})}{\partial \underline{\theta}^{\prime}}=\left(\begin{array}{cc}
-\mathbf{I}_{n} \otimes \mathbf{M}_{F} & \mathbf{0} \\
{[n(k+1)] \times[n(k+1)]} & {[n(k+1)] \times k} \\
-\mathbf{I}_{n} \otimes\left(\begin{array}{cc}
0 & \lambda^{\prime} \\
\text { scalar } &
\end{array}\right) & \underset{n \times k}{-\mathbf{B}}
\end{array}\right) .
\end{aligned}
$$

To replicate the estimates in the two-pass procedure, we need ${ }^{18}$

$$
\underset{[n(k+1)+k] \times[n(k+2)]}{\mathbf{a}_{T}}=\left(\begin{array}{cc}
\mathbf{I}_{n(k+1)} & \underset{n(k+1) \times n}{\mathbf{0}} \\
\underset{k \times n(k+1)}{\mathbf{0}} & \underset{k \times n}{\mathbf{B}^{\prime}}
\end{array}\right),
$$

${ }^{18}$ In the usual GMM problem, we minimize

$$
\underline{g}_{T}(\underline{\theta})^{\prime} \mathbf{S}_{T}^{-1} \underline{g}_{T}(\underline{\theta}),
$$

where

$$
\mathbf{S}_{T} \stackrel{\text { a.s. }}{\rightarrow} \mathbf{S}=\mathbf{E}\left(\sum_{j=-\infty}^{\infty} \underline{u}_{t}(\underline{\theta}) \underline{u}_{t-j}(\theta)^{\prime}\right) .
$$

We do Newey-West on $\underline{u}_{t}(\theta)$ to get $\mathbf{S}_{T}$. We will want to plug in our estimated $\lambda$ and $\beta s$ into $\mathbf{d}_{T}$. This problem chooses $\underline{\theta}$ to set

$$
\mathbf{d}_{T} \mathbf{S}_{T}^{-1} \underline{g}_{T}(\underline{\theta})=\underline{0}
$$

and can be recast as having a weighting matrix on the moment conditions

$$
\mathbf{a}_{T} \underline{g}_{T}(\underline{\theta})=0
$$

where

$$
\mathbf{a}_{T}=\mathbf{d}_{T} \mathbf{S}_{T}^{-1}
$$

The covariance matrix of $\underline{\theta}$ for this problem is,

$$
\mathbf{V}_{\theta}=\frac{1}{T}\left(\mathbf{d}_{T} \mathbf{S}_{T} \mathbf{d}_{T}\right)^{-1}
$$

but this is not the covariance matrix for the two-pass estimation problem. The reason is that the last set of $n$ moment conditions in $\underline{\mathbf{g}}_{T}(\underline{\theta})$ isn't the cross-sectional regression estimated by least squares (which is $\left.\mathbf{B}^{\prime}\left(\frac{1}{T} \sum_{t=1}^{T} \underline{R}_{t}^{e}-\mathbf{B} \underline{\lambda}\right)\right)$. 
not $\mathbf{d}_{T} \mathbf{S}_{T}^{-1}$. The coefficient covariance matrix we want is

$$
\mathbf{V}_{\theta}=\frac{1}{T}\left(\mathbf{a}_{T} \mathbf{d}_{T}\right)^{-1}\left(\mathbf{a}_{T} \mathbf{S}_{T} \mathbf{a}_{T}^{\prime}\right)\left[\left(\mathbf{a}_{T} \mathbf{d}_{T}\right)^{-1}\right]^{\prime}
$$

To test if the pricing errors are zero, use the covariance matrix of the moment conditions,

$$
\mathbf{V}_{g}=\frac{1}{T}\left(\mathbf{I}_{(n(k+1))}-\mathbf{d}_{T}\left(\mathbf{a}_{T} \mathbf{d}_{T}\right)^{-1} \mathbf{a}_{T}\right) \mathbf{S}_{T}\left(\mathbf{I}_{(n(k+2))}-\mathbf{d}_{T}\left(\mathbf{a}_{T} \mathbf{d}_{T}\right)^{-1} \mathbf{a}_{T}\right)
$$

We want to get $\mathbf{V}_{\theta}$ and $\mathbf{V}_{g}$ by plugging in.

GMM standard errors when estimating with a constant. The cross-sectional regression is now

$$
\frac{1}{T} \sum_{t=1}^{T} r_{i, t}^{e}=\gamma+\underline{\beta}_{i}^{\prime} \underline{\lambda}+\alpha_{i}
$$

where $\gamma$ is the constant. We have to add $\gamma$ to the coefficient vector $\theta$. Place it according to

$$
\underset{(n+1) \underline{\underline{\theta}}(k+1) \times 1}{\underline{\beta}}=\left(\begin{array}{c}
a_{1} \\
\underline{\beta}_{1} \\
\vdots \\
a_{n} \\
\underline{\beta}_{n} \\
\gamma \\
\underline{\lambda}
\end{array}\right)=\left(\begin{array}{c}
\tilde{\beta}_{1} \\
\vdots \\
\tilde{\beta}_{n} \\
\gamma \\
\underline{\lambda}
\end{array}\right) .
$$

Define

$$
\mathbf{X}=\left(\begin{array}{cc}
\underset{n \times 1}{ } & \mathbf{B} \\
n \times k
\end{array}\right) \text {. }
$$


The error vector that defines the model is

$$
\underline{u}_{t}(\underline{\theta})=\left(\begin{array}{c}
\underline{F}_{t}\left(r_{1, t}^{e}-\underline{F}_{t}^{\prime} \underline{\tilde{\beta}}_{1}\right) \\
\vdots \\
\underline{F}_{t}\left(r_{n, t}^{e}-\underline{F}_{t}^{\prime} \underline{\tilde{\beta}}_{n}\right) \\
r_{1, t}^{e}-\gamma-\underline{\beta}_{1}^{\prime} \underline{\lambda} \\
\vdots \\
r_{n, t}^{e}-\gamma-\underline{\beta}_{n}^{\prime} \underline{\lambda}
\end{array}\right)=\left(\begin{array}{c}
\underline{F}_{t}\left(r_{1, t}^{e}-\underline{F}_{t}^{\prime} \underline{\tilde{\beta}}_{1}\right) \\
\vdots \\
\underline{F}_{t}\left(r_{n, t}^{e}-\underline{F}_{t}^{\prime} \underline{\tilde{\beta}}_{n}\right) \\
\underline{R}_{t}^{e}-\mathbf{X}\left(\begin{array}{c}
\gamma \\
\underline{\lambda}
\end{array}\right)
\end{array}\right) .
$$

Do Newey-West on $\underline{u}_{t}(\theta)$ to get $\mathbf{S}_{T}$. Use

$$
\begin{aligned}
& \underset{[(n+1)(k+1)] \times[n(k+2)]}{\mathbf{a}_{T}}=\left(\begin{array}{cc}
\mathbf{I}_{n(k+1)} & \underset{[n(k+1)] \times n}{\mathbf{0}} \\
\underset{(k+1) \times[n(k+1)]}{\mathbf{0}} & \underset{(k+1) \times n}{\mathbf{X}^{\prime}}
\end{array}\right)
\end{aligned}
$$

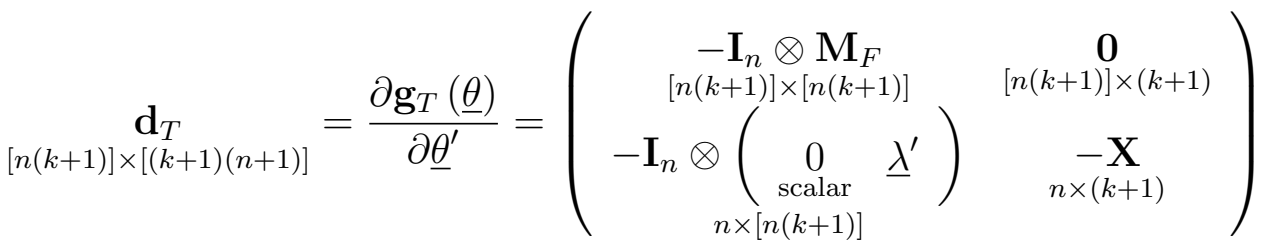

to plug into (21) and (22).

We do not use GMM to estimate the model. We use the two-step procedure to get the point estimates for the betas and lambdas and plug those estimates into the GMM formulae to get standard errors. 


\section{Appendix C}

\section{Alternative Window Sizes}

This appendix reports estimations of the beta model when the relevant moments are computed with windows of 16 and 20 quarters. 
Table 14: Two-Pass Estimation of the Two-Factor Beta-Risk Model on Carry Excess Returns, 1977Q1-2014Q2

\begin{tabular}{|c|c|c|c|c|c|c|c|c|c|c|c|c|c|c|c|}
\hline Factor & $\lambda_{1}$ & $\lambda_{\text {skew }}$ & $\gamma$ & $R^{2}$ & $\begin{array}{r}\text { Test- } \\
\text { stat }\end{array}$ & $\lambda_{1}$ & $\lambda_{v o l}$ & $\gamma$ & $R^{2}$ & $\begin{array}{r}\text { Test- } \\
\text { stat }\end{array}$ & $\lambda_{1}$ & $\lambda_{\text {mean }}$ & $\gamma$ & $R^{2}$ & $\begin{array}{r}\text { Test- } \\
\text { stat }\end{array}$ \\
\hline$U E^{g a p}$ & - & - & - & - & - & $0.727^{*}$ & 1.415 & 7.217 & 0.899 & 1.694 & $0.473^{*}$ & 2.080 & 3.754 & 0.913 & 2.674 \\
\hline & - & - & - & - & - & {$[1.778]$} & {$[0.595]$} & {$[1.570]$} & & $(0.890)$ & {$[1.731]$} & [1.318] & {$[1.279]$} & & $(0.750)$ \\
\hline$\Delta U E$ & $\begin{array}{c}0.685^{*} \\
{[1.947]}\end{array}$ & $\begin{array}{l}0.462^{*} \\
{[1.789]}\end{array}$ & $\begin{array}{r}\mathbf{6 . 2 7 6} \\
{[2.059]}\end{array}$ & 0.865 & $\begin{array}{r}0.948 \\
(0.967)\end{array}$ & $\begin{array}{l}1.004^{*} \\
{[1.702]}\end{array}$ & $\begin{array}{r}0.026 \\
{[0.297]}\end{array}$ & $\begin{array}{r}7.314 \\
{[1.431]}\end{array}$ & 0.947 & $\begin{array}{r}0.532 \\
(0.991)\end{array}$ & $\begin{array}{l}0.704^{*} \\
{[1.888]}\end{array}$ & $\begin{array}{r}0.044 \\
{[1.080]}\end{array}$ & $\begin{array}{r}3.965 \\
{[1.210]}\end{array}$ & 0.999 & $\begin{array}{r}0.021 \\
(1.000)\end{array}$ \\
\hline$y^{g a p}$ & $\begin{array}{l}0.911^{*} \\
{[1.802]}\end{array}$ & $\begin{array}{r}1.045 \\
{[0.969]}\end{array}$ & $\begin{array}{l}10.344 \\
{[1.361]}\end{array}$ & 0.932 & $\begin{array}{r}0.523 \\
(0.991)\end{array}$ & $\begin{array}{l}0.521^{*} \\
{[1.942]}\end{array}$ & $\begin{array}{l}0.626^{*} \\
{[1.787]}\end{array}$ & $\begin{array}{r}3.659 \\
{[1.224]}\end{array}$ & 0.965 & $\begin{array}{r}0.844 \\
(0.974)\end{array}$ & $\begin{array}{l}0.584^{*} \\
{[1.930]}\end{array}$ & $\begin{array}{r}0.665 \\
{[1.554]}\end{array}$ & $\begin{array}{r}3.876 \\
{[1.246]}\end{array}$ & 0.891 & $\begin{array}{r}2.396 \\
(0.792)\end{array}$ \\
\hline$\Delta y$ & $\begin{array}{r}\mathbf{0 . 8 8 2} \\
{[2.152]}\end{array}$ & $\begin{array}{r}0.272 \\
{[0.763]}\end{array}$ & $\begin{array}{r}\mathbf{7 . 3 4 5} \\
{[2.159]}\end{array}$ & 0.847 & $\begin{array}{r}1.473 \\
(0.916)\end{array}$ & $\begin{array}{c}0.677^{*} \\
{[1.823]}\end{array}$ & $\begin{array}{l}1.303^{*} \\
{[1.923]}\end{array}$ & $\begin{array}{r}4.353 \\
{[1.387]}\end{array}$ & 0.996 & $\begin{array}{r}0.167 \\
(0.999)\end{array}$ & $\begin{array}{l}1.010^{*} \\
{[1.688]}\end{array}$ & $\begin{array}{r}-0.262 \\
{[-0.140]}\end{array}$ & $\begin{array}{r}6.780 \\
{[1.606]}\end{array}$ & 0.895 & $\begin{array}{r}0.611 \\
(0.987)\end{array}$ \\
\hline$q^{g a p}$ & $\begin{array}{c}0.830^{*} \\
{[1.853]}\end{array}$ & $\begin{array}{r}-0.072 \\
{[-0.156]}\end{array}$ & $\begin{array}{r}6.682 \\
{[1.248]}\end{array}$ & 0.849 & $\begin{array}{r}1.656 \\
(0.894)\end{array}$ & $\begin{array}{r}\mathbf{0 . 5 9 7} \\
{[2.253]}\end{array}$ & $\begin{array}{r}\mathbf{3 . 8 3 5} \\
{[2.211]}\end{array}$ & $\begin{array}{r}4.379 \\
{[1.527]}\end{array}$ & 0.892 & $\begin{array}{r}2.667 \\
(0.751)\end{array}$ & $\begin{array}{l}0.717^{*} \\
{[1.907]}\end{array}$ & $\begin{array}{r}0.944 \\
{[0.992]}\end{array}$ & $\begin{array}{l}5.961^{*} \\
{[1.798]}\end{array}$ & 0.764 & $\begin{array}{r}2.789 \\
(0.733)\end{array}$ \\
\hline$\Delta q$ & $\begin{array}{r}\mathbf{0 . 8 4 3} \\
{[1.979]}\end{array}$ & $\begin{array}{r}0.515 \\
{[0.635]}\end{array}$ & $\begin{array}{l}9.171^{*} \\
{[1.755]}\end{array}$ & 0.871 & $\begin{array}{r}1.114 \\
(0.953)\end{array}$ & $\begin{array}{l}0.849^{*} \\
{[1.928]}\end{array}$ & $\begin{array}{r}8.984 \\
{[0.994]}\end{array}$ & $\begin{array}{l}6.987^{*} \\
{[1.713]}\end{array}$ & 0.888 & $\begin{array}{r}1.028 \\
(0.960)\end{array}$ & $\begin{array}{l}0.941^{*} \\
{[1.941]}\end{array}$ & $\begin{array}{r}2.703 \\
{[1.309]}\end{array}$ & $\begin{array}{l}6.243^{*} \\
{[1.680]}\end{array}$ & 0.944 & $\begin{array}{r}0.600 \\
(0.988)\end{array}$ \\
\hline$\Delta c$ & $\begin{array}{r}\mathbf{0 . 8 5 5} \\
{[2.058]}\end{array}$ & $\begin{array}{r}0.421 \\
{[1.264]}\end{array}$ & $\begin{array}{l}6.427^{*} \\
{[1.748]}\end{array}$ & 0.994 & $\begin{array}{r}0.077 \\
(1.000)\end{array}$ & $\begin{array}{r}0.587 \\
{[1.548]}\end{array}$ & $\begin{array}{l}\mathbf{1 . 0 0 2} \\
{[2.364]}\end{array}$ & $\begin{array}{r}3.223 \\
{[0.916]}\end{array}$ & 0.984 & $\begin{array}{r}0.451 \\
(0.994)\end{array}$ & $\begin{array}{r}0.926 \\
{[1.622]}\end{array}$ & $\begin{array}{r}-0.707 \\
{[-0.465]}\end{array}$ & $\begin{array}{l}6.685^{*} \\
{[1.745]}\end{array}$ & 0.872 & $\begin{array}{r}1.101 \\
(0.954)\end{array}$ \\
\hline$\pi$ & $\begin{array}{r}\mathbf{0 . 8 8 3} \\
{[2.134]}\end{array}$ & $\begin{array}{r}-0.139 \\
{[-0.376]}\end{array}$ & $\begin{array}{r}7.994 \\
{[1.550]}\end{array}$ & 0.846 & $\begin{array}{r}1.492 \\
(0.914) \\
\end{array}$ & $\begin{array}{r}\mathbf{0 . 6 8 6} \\
{[1.968]}\end{array}$ & $\begin{array}{r}\mathbf{2 . 7 7 5} \\
{[2.523]}\end{array}$ & $\begin{array}{r}4.630 \\
{[1.568]}\end{array}$ & 0.987 & $\begin{array}{r}0.538 \\
(0.991) \\
\end{array}$ & $\begin{array}{r}\mathbf{0 . 7 0 7} \\
{[2.037]}\end{array}$ & $\begin{array}{r}\mathbf{7 . 4 3 3} \\
{[2.482]}\end{array}$ & $\begin{array}{l}5.029^{*} \\
{[1.700]}\end{array}$ & 0.982 & $\begin{array}{r}0.747 \\
(0.980) \\
\end{array}$ \\
\hline
\end{tabular}

Notes: We estimate a two-factor model with the $\mathrm{HML}_{\text {skew }}$ of the $U E^{g a p}$ as the maintained first factor (associated with $\lambda_{1}$ ) and each of the alternative factor constructions as the second factor (associated with $\lambda_{s k e w}, \lambda_{v o l}$, and $\lambda_{\text {mean }}$ ) to assess the impression that HML $\mathrm{H}_{\text {sew }}$ of the $U E^{\text {gap }}$ is the dominant factor. 16 quarters

start-up to compute initial high-minus-low factors. Model estimated on returns from 1977Q1 to 2014Q2. See notes to Table 1. 
Table 15: Two-Pass Estimation of the Two-Factor Beta-Risk Model on Carry Excess Returns, 1978Q1-2014Q2

\begin{tabular}{|c|c|c|c|c|c|c|c|c|c|c|c|c|c|c|c|}
\hline Factor & $\lambda_{1}$ & $\lambda_{\text {skew }}$ & $\gamma$ & $R^{2}$ & $\begin{array}{r}\text { Test- } \\
\text { stat }\end{array}$ & $\lambda_{1}$ & $\lambda_{v o l}$ & $\gamma$ & $R^{2}$ & $\begin{array}{r}\text { Test- } \\
\text { stat }\end{array}$ & $\lambda_{1}$ & $\lambda_{\text {mean }}$ & $\gamma$ & $R^{2}$ & $\begin{array}{l}\text { Test- } \\
\text { stat }\end{array}$ \\
\hline \multirow[t]{2}{*}{$U E^{g a p}$} & - & - & - & - & - & 0.372 & -0.670 & 1.949 & 0.955 & 2.347 & $0.371^{*}$ & -0.034 & 2.003 & 0.954 & 1.829 \\
\hline & - & - & - & - & - & [2.842] & {$[-0.579]$} & [0.810] & & (0.799) & [1.930] & {$[-0.017]$} & {$[0.896]$} & & $(0.872)$ \\
\hline \multirow[t]{2}{*}{$\Delta U E$} & 0.438 & 0.292 & 1.801 & 0.979 & 1.000 & 0.412 & -0.037 & 1.606 & 0.937 & 2.729 & 0.397 & -0.007 & 1.562 & 0.921 & 2.506 \\
\hline & [3.025] & [1.271] & {$[0.830]$} & & (0.963) & {$[3.075]$} & {$[-1.156]$} & {$[0.676]$} & & $(0.742)$ & {$[2.670]$} & {$[-0.217]$} & {$[0.673]$} & & $(0.776)$ \\
\hline \multirow[t]{2}{*}{$y^{g a p}$} & 0.451 & 0.203 & 2.108 & 0.987 & 0.574 & 0.353 & 0.366 & 1.610 & 0.968 & 1.087 & 0.414 & 0.094 & 2.184 & 0.960 & 1.771 \\
\hline & {$[3.076]$} & {$[0.642]$} & {$[0.680]$} & & $(0.989)$ & {$[2.864]$} & {$[1.456]$} & {$[0.694]$} & & $(0.955)$ & [2.534] & {$[0.344]$} & [0.945] & & $(0.880)$ \\
\hline \multirow[t]{2}{*}{$\Delta y$} & 0.452 & 0.115 & 2.093 & 0.988 & 0.484 & 0.444 & 0.465 & 1.892 & 0.931 & 2.321 & 0.432 & -1.077 & 2.399 & 0.955 & 2.179 \\
\hline & [3.460] & [0.587] & [0.864] & & (0.993) & [2.851] & {$[0.817]$} & [0.773] & & $(0.803)$ & [3.335] & [-1.573] & [0.959] & & $(0.824)$ \\
\hline \multirow[t]{2}{*}{$q^{g a p}$} & 0.423 & -0.019 & 1.946 & 0.981 & 0.850 & 0.361 & 1.352 & 1.961 & 0.955 & 2.469 & 0.349 & -0.079 & 1.269 & 0.977 & 1.029 \\
\hline & [3.216] & {$[-0.044]$} & [0.657] & & $(0.974)$ & [3.207] & [0.861] & [0.905] & & $(0.781)$ & [2.781] & {$[-0.175]$} & {$[0.506]$} & & $(0.960)$ \\
\hline \multirow[t]{2}{*}{$\Delta q$} & 0.443 & 0.044 & 2.162 & 0.987 & 0.807 & 0.349 & 8.082 & 3.782 & 0.955 & 2.902 & 0.395 & -0.049 & 2.190 & 0.935 & 2.697 \\
\hline & [2.449] & {$[0.074]$} & {$[0.666]$} & & $(0.977)$ & {$[3.146]$} & [1.184] & [0.902] & & $(0.715)$ & [3.213] & {$[-0.045]$} & {$[0.858]$} & & $(0.747)$ \\
\hline \multirow[t]{2}{*}{$\Delta c$} & 0.473 & -0.017 & 2.006 & 0.988 & 0.824 & 0.364 & 0.815 & 0.347 & 0.936 & 1.722 & 0.423 & -0.885 & 2.347 & 0.953 & 2.197 \\
\hline & {$[2.742]$} & {$[-0.108]$} & {$[0.966]$} & & $(0.975)$ & {$[2.916]$} & {$[1.455]$} & {$[0.127]$} & & $(0.886)$ & [3.605] & {$[-1.376]$} & {$[0.961]$} & & $(0.821)$ \\
\hline \multirow[t]{2}{*}{$\pi$} & 0.492 & -0.119 & 3.702 & 0.997 & 0.068 & 0.397 & 0.875 & 1.776 & 0.928 & 2.802 & 0.395 & 2.204 & 1.421 & 0.923 & 2.745 \\
\hline & [3.384] & {$[-0.654]$} & [1.177] & & $(1.000)$ & {$[3.165]$} & {$[0.949]$} & {$[0.747]$} & & $(0.730)$ & {$[3.032]$} & {$[0.841]$} & {$[0.598]$} & & $(0.739)$ \\
\hline
\end{tabular}

Notes: We estimate a two-factor model with the $\mathrm{HML}_{\text {skew }}$ of the $U E^{g a p}$ as the maintained first factor (associated with $\lambda_{1}$ ) and each of the alternative factor constructions as the second factor (associated with $\lambda_{\text {skew }}, \lambda_{\text {vol }}$, and $\lambda_{\text {mean }}$ ) to assess the impression that HML $\mathrm{H}_{\text {sew }}$ of the $U E^{\text {gap }}$ is the dominant factor. 20 quarters

start-up to compute initial high-minus-low factors. Model estimated on returns from 1978Q1 to 2014Q2. See notes to Table 1. 